\title{
Compensation between Wnt-driven tumorigenesis and cellular responses to ribosome biogenesis inhibition in the murine intestinal epithelium
}

\author{
Aurélien Raveux $^{1,2} \cdot$ Aline Stedman $^{1,7} \cdot$ Sabrina Coqueran $^{1} \cdot$ Sandrine Vandormael-Pournin $^{1} \cdot$ Nick $^{\text {Owens }}{ }^{3} \cdot$

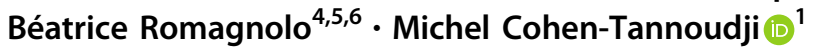

Received: 17 July 2019 / Revised: 6 April 2020 / Accepted: 8 April 2020 / Published online: 30 April 2020

(c) The Author(s), under exclusive licence to ADMC Associazione Differenziamento e Morte Cellulare 2020

\begin{abstract}
Ribosome biogenesis inhibition causes cell cycle arrest and apoptosis through the activation of tumor suppressor-dependent surveillance pathways. These responses are exacerbated in cancer cells, suggesting that targeting ribosome synthesis may be beneficial to patients. Here, we characterize the effect of the loss-of-function of Notchless (Nle), an essential actor of ribosome biogenesis, on the intestinal epithelium undergoing tumor initiation due to acute Apc loss-of-function. We show that ribosome biogenesis dysfunction strongly alleviates Wnt-driven tumor initiation by restoring cell cycle exit and differentiation in Apc-deficient progenitors. Conversely Wnt hyperactivation attenuates the cellular responses to surveillance pathways activation induced by ribosome biogenesis dysfunction, as proliferation was maintained at control-like levels in the stem cells and progenitors of double mutants. Thus, our data indicate that, while ribosome biogenesis inhibition efficiently reduces cancer cell proliferation in the intestinal epithelium, enhanced resistance of $A p c$-deficient stem and progenitor cells to ribosome biogenesis defects may be an important concern when using a therapeutic strategy targeting ribosome production for the treatment of Wnt-dependent tumorigenesis.
\end{abstract}

These authors contributed equally: Aurélien Raveux, Aline Stedman

Edited by Y. Shi

Supplementary information The online version of this article (https:// doi.org/10.1038/s41418-020-0548-6) contains supplementary material, which is available to authorized users.

Michel Cohen-Tannoudji

m-cohen@pasteur.fr

1 Early Mammalian Development and Stem Cell Biology, Institut Pasteur, CNRS UMR 3738, 25 rue du Dr. Roux, F-75015 Paris, France

2 Sorbonne Université, Collège Doctoral, F-75005 Paris, France

3 Epigenetics of Stem Cells, Department of Developmental and Stem Cell Biology, Institut Pasteur, CNRS UMR 3738, 25 rue du Docteur Roux, F-75015 Paris, France

4 Inserm, U1016, Institut Cochin, Paris, France

5 CNRS UMR 8104, Paris, France

6 Université Paris Descartes, Sorbonne Paris Cité, Paris, France

7 Present address: Sorbonne Université, CNRS UMR 7622, Inserm U1156, Institut de Biologie Paris Seine-Laboratoire de Biologie du Développement, 9 Quai Saint Bernard, F-75005 Paris, France

\section{Introduction}

Ribosome biogenesis inhibition has emerged as a promising therapeutic strategy against cancer. Indeed, in addition to targeting the production of the ribosomes required for the increased protein synthesis demand of cancer cells [1], RNA Pol I inhibition or deficiencies in ribosome biogenesis factors were shown to trigger the binding of a 5S rRNA/ RPL11/RPL5 inhibitory complex to MDM2, thereby preventing p53 degradation [2-4]. In absence of functional p53 pathway, ribosome biogenesis dysfunction also triggers p53-independent mechanisms [5]. Taking advantage of specific RNA Pol I inhibitors, several in vitro and xenograft studies have shown that lymphoma [6], melanoma, osteosarcoma, breast, colon [7], and lung [8] cancer cells display a strong and specific sensitivity to ribosome biogenesis inhibition, that induces potent p53-dependent or independent stress responses, which are not observed in normal cells $[6,7]$. As a therapeutic strategy, targeting the translational apparatus of cancer cells has two major advantages. First, it is non-genotoxic and therefore minimizes the risk of inducing novel mutations in the surrounding cells. Second, this approach displayed so far a clear differential effect 
between normal cells and the tested cancer cell lines, making it theoretically possible to establish a dosage that reduces deleterious side effects while still being efficient. However, the impact of ribosome biogenesis alterations on tissues undergoing tumorigenesis in vivo has insufficiently been assessed until now.

In humans, APC is mutated in the vast majority of colorectal cancers [9]. In the mouse, the acute inactivation of $A p c$ in the epithelium of the small intestine results in constitutive activation of the $\mathrm{Wnt} / \beta$-catenin pathway, leading to an abnormal expansion of the proliferative compartment at the expense of differentiated cells, reminiscent of early events of adenoma formation [10, 11]. It has been shown that $M y c$ deletion largely rescues the Apc loss-of-function phenotype through downstream shutdown of the Wnt pathway [12], suggesting that Wnt-driven tumor initiation is also Myc-driven. Interestingly, the aforementioned Pol I inhibitors were demonstrated to be particularly efficient on Myc-driven cancer cells [6, 8]. Since c-MYC is a major ribosome biogenesis positive regulator [13], this raised the possibility that ribosome biogenesis inhibition could also attenuate the phenotype caused by Apc deficiency.

Notchless (Nle) encodes a WD40 repeats-containing protein highly conserved in eukaryotes [14-16] and involved in the late steps of maturation and subsequent export of the $60 \mathrm{~S}$ particle [17-20]. In previous studies, we showed that the role of Nle in the maturation of the large ribosomal subunit is conserved in the mouse [21], and that Nle loss-of-function leads to p53 activation in the intestinal epithelium, resulting in rapid stem cell and progenitor exhaustion through cell cycle arrest, apoptosis and premature goblet cell differentiation [22]. This genetic model offers a unique opportunity to study the impact of ribosome biogenesis perturbations specifically in the intestinal epithelium under pathological conditions. Here, by combining Nle and Apc conditional loss-of-function, we show that defective ribosome biogenesis strongly attenuates Wnt hyperactivation-driven proliferative compartment expansion in the intestinal epithelium through restoration of cell cycle exit and differentiation. Conversely, we show that Wnt hyperactivation alleviates the Nle loss-of-function phenotype, as proliferation is maintained in double mutant crypts and in the stem cell compartment despite broad and persistent p53 stabilization.

\section{Material and methods}

\section{Mice}

All experiments were conducted at the Institut Pasteur according to the French and European regulations on care and protection of laboratory animals (EC Directive 86/609,
French Law 2001-486 issued on June 6, 2001) and were approved by the Institut Pasteur ethics committee (nos. 2016-0106 and 2017-0044).

The alleles used were as follows: $N l e^{f l o x}$ [21], $N l e^{\text {null }}[15]$, $A p c^{\text {flox }}$ [10], and Villin-CreERT2 [23]. All experimental animals were generated in a mixed C57BL/6Nx129/Sv genetic background. Mice at 5-10 weeks of age were injected intraperitoneally with $56 \mathrm{mg} / \mathrm{kg}$ tamoxifen for 3 consecutive days. For proliferation assays, mice were injected with $\mathrm{BrdU}(100 \mathrm{mg} / \mathrm{kg}) 2,24$, or $48 \mathrm{~h}$ before sacrifice. Injection order was randomized between animals and genotype was only assessed after the experiments.

Genotyping was performed by PCR after tissue lysis in $50 \mathrm{mM}$ Tris, $\mathrm{pH} 8.5,100 \mathrm{mM} \mathrm{NaCl}, 0.5 \%$ Tween 20 , and $100 \mathrm{mg} / \mathrm{ml}$ proteinase $\mathrm{K}$ at $56^{\circ} \mathrm{C}$ overnight, followed by a 10-min incubation at $96^{\circ} \mathrm{C}$. PCR was performed using 1 unit of Taq DNA polymerase (MP biomedicals) under the following conditions: $95^{\circ} \mathrm{C}$ for $30 \mathrm{~s} ; 32$ cycles at $95^{\circ} \mathrm{C}$ for $30 \mathrm{~s}$, $60{ }^{\circ} \mathrm{C}$ for $30 \mathrm{~s}, 72{ }^{\circ} \mathrm{C}$ for $60 \mathrm{~s} ; 72{ }^{\circ} \mathrm{C}$ for $10 \mathrm{~min}$. For Nle, PCR amplification with primers mNleQF3 (5'-ctgtactcttctcatccgaccac-3'), CondF ( $5^{\prime}$-agacttggggtctggactca- $\left.3^{\prime}\right)$, and CondR2 $\left(5^{\prime}\right.$-ccctaactaagacaaccaaga- $\left.3^{\prime}\right)$ allowed us to discriminate $N e^{w t}$ (112 bp), Nle Flox (216 bp), and Nled (635 bp) alleles. For Apc, PCR amplification with primers APCint13F (5'-ctgttctgcagtatgttatca-3'), APCext14R (5'-ctatgagtcaaca caggatta-3'), and APCext15R ( $5^{\prime}$-caatataatgagctctgggcc-3') allowed us to discriminate $A P C^{w t}$ (180 bp), $A p c^{\text {Flox }}$ (230 bp), and $A p c^{d e l}$ (160 bp) alleles. PCR products were separated by electrophoresis on 2\% high-resolution (NuSieve 3:1 agarose) agarose gels.

\section{Tissue extracts}

For paraffin sections, the intestinal tract was dissected, then flushed with ice-cold PBS to remove feces and perfused with ice-cold $4 \%$ paraformaldehyde (PFA). The small intestine was rolled up from the proximal to the distal end in concentric circles, fixed in $4 \%$ PFA at $4{ }^{\circ} \mathrm{C}$ overnight and embedded in paraffin wax. For RT-qPCR on total epithelium, $5 \mathrm{~cm}$ of duodenum was harvested in $10 \mathrm{~mL}$ EDTA ( $10 \mathrm{mM}$ in PBS, $\mathrm{pH}=8.0$ ). After $30 \mathrm{~min}$ incubation on ice and $2 \times 5$ min vortex at maximum speed at $4{ }^{\circ} \mathrm{C}$, the muscle layer of the intestine was manually removed and the epithelium was pelleted at $300 \mathrm{rcf}, 4{ }^{\circ} \mathrm{C}$ for $5 \mathrm{~min}$, then resuspended in $1 \mathrm{~mL}$ Trizol (Invitrogen, Carlsbad, CA, USA). For crypts and villi isolation, $5-10 \mathrm{~cm}$ of jejunum were collected, opened longitudinally and processed as previously described [24].

\section{Histology and immunostaining}

Histology and immunostaining were performed as described previously [25]. Specific antibody binding was detected 
using biotinylated secondary antibodies and Streptavidin/ HRP complexes (Dako, Glostrup, Denmark). For $\beta$-catenin immunostaining, M.O.M. and ABC kits (Vector) were used. Bright-field microscopy was performed using a Axio Scan. $\mathrm{Z} 1$ equipped with $\mathrm{a} \times 20$ objective lens. The system was set to run in automated batch mode with automated focus and tissue finding. Primary and secondary antibodies used in this study are listed in Supplementary material (Supplementary Table S1).

\section{In situ hybridization}

For Fluorescent In Situ Hybridization (FISH), the hybridization step was performed as previously described. Conjugated FISH probes were purchased from Eurogentec: its1-Cy5: tagacacggaagagccggacgggaaaga; its2-Cy3: gcgattgatcgtcaacc gacgctc and validated in a previous study [21]. ISH for Olfm4 was carried out with the RNAscope 2.5 BROWN kit (Advanced Cell Diagnostics) according to the manufacturer's instructions (Olfm4 probe reference: 311831).

\section{RT-qPCR}

RNA extraction was performed according to the Trizolchloroform extraction protocol provided by Invitrogen. For epithelium, crypts and villi, the chloroform and ethanol steps were repeated twice. Reverse-transcription was performed using the Superscript II kit (Invitrogen) according to the manufacturer's instructions. Real-time PCR was carried on using custom-designed primers (Supplementary Table S2) and LightCycler 480 SYBR Green I Master mix (Roche Life Sciences) on a LightCycler 480 (Roche Life Sciences). Expression levels were normalized using TBP and Aldolase as reference genes.

\section{Western blot}

Proteins were extracted in a buffer containing $10 \mathrm{mM}$ Tris$\mathrm{HCl} \mathrm{pH} 7.5,5 \mathrm{mM}$ EDTA, $150 \mathrm{mM} \mathrm{NaCl}, 30 \mathrm{mM}$ Sodium Pyrophosphate, $50 \mathrm{mM}$ Sodium Fluoride, 10\% Glycerol, $1 \%$ NP40, supplemented with antiproteases (Roche Life Sciences) and $2.5 \mathrm{U} / \mu \mathrm{L}$ Benzonase (Sigma-Aldrich). The extracts were incubated on ice for $30 \mathrm{~min}$, then centrifuged $10 \mathrm{~min}$ at $10,000 \mathrm{rcf}, 4^{\circ} \mathrm{C}$. The supernatant was recovered and its protein content was determined using a Bradford assay. Proteins were denatured in Laemmli buffer at $95^{\circ} \mathrm{C}$ for $5 \mathrm{~min}$ before being loaded on a $12 \%$ polyacrylamide gel. After migration, proteins were transferred onto a nitrocellulose membrane (Biorad, Hercules, CA, USA) and incubated overnight at $4{ }^{\circ} \mathrm{C}$ with the primary antibodies. Membranes were incubated with peroxidase-labeled secondary antibodies at RT for $80 \mathrm{~min}$ and rinsed in TBS- $0.1 \%$ Tween. Signals were visualized using ECl 2 (Pierce Biotechnology,
Rockford, IL, USA) and quantified on a Typhoon Instrument. Primary and secondary antibodies used in these experiments are listed in Supplementary Table S1.

\section{Quantification of protein synthesis}

Mice were injected intraperitoneally with $2 \mathrm{mg}$ of puromycin in PBS, 10 min before sacrifice. Intestines were rapidly harvested in ice-cold PBS containing emetine to block further puromycin incorporation during the procedure. Crypts were isolated as previously described [24] and counted before being lysed in protein extraction buffer. Puromycilated peptide chains were quantified on a western blot against puromycin by measuring the pixel intensity through the whole length of each lane using a Typhoon instrument.

\section{Crypts culture}

Isolated crypts were cultured as previously described [26]. In brief, crypts were embedded in growth factor reduced matrigel (Corning Life Sciences, Tewksbury, MA, USA) with culture medium (Advanced DMEM/F12; Invitrogen) containing EGF (Peprotech, Rocky Hill, NJ, USA), R-spondin 1 (R\&D Systems, Minneapolis, MN, USA), Noggin (Peprotech) and B27 (Invitrogen). For nutlin-3 treatment, 4- or 8-day-old organoids derived from Control or $\mathrm{APC}^{\mathrm{cKO}}$ crypts were incubated with culture medium containing DMSO (mock condition) or nutlin-3a (Sigma) at 1,5 , and $10 \mu \mathrm{M}$ concentrations. After 2 days of treatment, the number of healthy organoids was scored manually. Images of representative organoids were acquired with a bright-field Leica MZ16 binocular (Leica, M165FC). Healthy organoids were defined as budding structures with at least three buds and visible lumen for Control, and smooth spheres with visible lumen for $\mathrm{APC}^{\mathrm{cKO}}$. Two mice per genotype and 2-3 technical replicates per condition were assessed. For immunofluorescence, organoids were fixed in $4 \%$ formaldehyde for $2 \mathrm{~h}$ at RT, permeabilized with Blocking Buffer (5\% fetal calf serum, $0.5 \%$ Triton X100 in $1 \times$ PBS) and incubated with appropriate primary and secondary antibodies. Phalloidin (1/50; Thermofisher) and DAPI (1/1000; Sigma) were used to detect cell membranes and nuclei, respectively. Samples were washed three times in PBS before being imaged on the macroapotome Zeiss Axiozoomer and analyzed using the Zen software.

\section{Statistical analysis}

All experiments were performed with a sample size $n \geq 4$ (each sample is an individual mouse) so as to dampen the influence of outliers on means. No animal was excluded 
from the analysis. For mean comparisons, all bar graphs with pooled data show means \pm S.E.M. Statistical analyses were performed using the parametric Student's $t$ test and the non-parametric Mann-Whitney Wilcoxon test to account for the possibility of non-normal distributions. $p<0.05$ was considered significant. Tests were always two sided.

\section{RNA sequencing}

Crypts were harvested at day 1 and day 2 pi from three mice of each genotype and total RNA was prepared using Trizol-chloroform extraction. PolyA-enriched library preparation and PE150 sequencing were performed by Novogene Co. Ltd. Approximately 20 million sequences were generated per sample and used for the analysis. The sequence data have been deposited in NCBI's Gene Expression Omnibus under accession number GSE144233.

\section{Computational methods}

\section{RNA-seq data processing and differential expression}

Paired end RNA-seq reads were quantified against the mm9 transcriptome using Kallisto 0.43 [27] with default options. Rounded estimated counts were used as input to DESeq2 [28]. Genes with at least ten normalized counts in all replicates of at least one condition were considered for differential expression analysis. For all differential expression tests DESeq2 was run without independent filtering and without any fold change shrinkage, genes with padj $<0.05$ are considered differentially expressed. Samples at day 1 and day 2 were processed separately and subjected to the same analysis. We performed Wald tests under the model $\sim \mathrm{Nle}+\mathrm{Apc}+\mathrm{Nle:Apc}$, where Nle is a factor indicating $\mathrm{Nl}^{\mathrm{cKO}}$ and $\mathrm{Apc}$ is a factor indicating $\mathrm{Apc}^{\mathrm{cKO}}$. Roughly, for each gene, the fold changes in $\mathrm{Nle}^{\mathrm{cKO}}$ samples $(\mathrm{N})$ and in $\mathrm{Apc}^{\mathrm{cKO}}$ samples (A) were calculated. The interaction term (D) indicates that, for a given gene, the fold change in $\mathrm{Apc}^{\mathrm{cKO}}$; $\mathrm{Nl}^{\mathrm{cKO}}$ samples differs from $\mathrm{N} \times \mathrm{A}$. We tested the significance of the Nle, Apc, and the interaction term.

\section{K-means clustering of RNA-seq data}

Response patterns of genes were identified using k-means clustering (using the Clustering package in Julia 0.6 [29]) on normalized read counts. We clustered the mean expression per time point and condition, normalized to the maximum expression of each gene. We found $k=10$ provided a balance, both generalizing broad behaviors and identify specific double cKO results.

\section{Gene/phenotype ontology enrichment analysis}

Genes were annotated with gene ontology (GO) terms (transitively closed to include parent terms) from the MGI GO annotation (date: 26/01/2017). Enrichment tests were applied to gene lists resulting from differential expression analysis. In all cases, enrichment tests were performed using $\chi^{2}$ tests for all terms with at least 5 genes in the gene list of interest against a background of annotations of all genes tested for differential expression. $\chi^{2}$ test $p$ values were adjusted by the Benjamini-Hochberg method, those with padj $<0.05$ where reported.

The different gene clusters from the model-based analysis were also analyzed using the MouseMine database. For each gene list, Mammalian Phenotype Ontology Enrichment terms were searched with Max $p$ value $=0.05$ and Holm-Bonferroni correction. When significantly enriched terms were found, those relevant to our mutant phenotypes were selected, and the term with the lowest $p$ value for each category was indicated on Figs. 5e and S5. For every analysis, $p<0.05$ is considered significant.

\section{Results}

\section{Nle loss-of-function improves survival of Apc- deficient mice and limits expansion of the crypt compartment}

Control (Villin-CreERT2 ${ }^{\mathrm{tg} / 0} ; A p c^{f l o x /+} ; \mathrm{Nl}^{f l o x /+}$ ), Apc $\mathrm{AKO}^{\mathrm{KKO}}$ (Villin-CreERT2 $2^{\mathrm{tg} / 0} ; A p c^{f l o x / f l o x} ; \mathrm{Nl}^{f l o x /+}$ ) and $\mathrm{Apc}^{\mathrm{cKO}}$; $\mathrm{Nle}^{\text {cKO }}$ (Villin-CreERT2 ${ }^{\mathrm{tg} / 0} ; A p c^{\text {flox/flox }} ; \mathrm{Nl}^{\text {flox/null }}$ ) mice were subjected to three daily intraperitoneal tamoxifen injections and analyzed at various time points post last tamoxifen injection (pi) (Fig. 1a). Conversion of the $A p c^{f l o x}$ and $N l e^{f o x}$ alleles into $A p c^{d e l}$ and $N l e^{d e l}$ alleles respectively was monitored by genomic PCR on both loci. We found that recombination of the $A p c^{f l o x}$ and $N l e^{f o x}$ alleles was efficient in the intestinal epithelium from Control, $\mathrm{Apc}^{\mathrm{cKO}}$ and $\mathrm{Apc}^{\mathrm{cKO}} ; \mathrm{Nle}^{\mathrm{cKO}}$ mice (Fig. 1b). Apc ${ }^{\mathrm{CKO}}$ mice lost weight and died rapidly following tamoxifen injection. Weight loss was significantly reduced in double mutant mice (Fig. 1c), and although persisting, their death was significantly delayed compared with the $\mathrm{Apc}^{\mathrm{cKO}}$ (Fig. 1d).

Consistent with previous reports $[10,11]$, hematoxylineosin staining showed that $A p c$ loss-of-function resulted in rapid expansion of the crypt compartment at the expense of the villus (Fig. 1e), loss of typical enterocyte polarity and abnormal nuclear morphology (Fig. S1A). Nle loss-offunction strongly dampened these histological alterations (Fig. 1e), as the enlarged crypt compartment was not observed, and cell polarity was restored in the villus (Fig. S1A). Other aspects of the Apc loss-of-function 
A

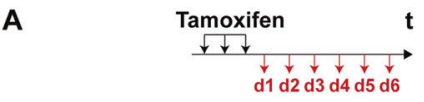$$
\begin{aligned}
& B \\
& \frac{2}{4} \\
& \frac{2}{2}
\end{aligned}
$$

C

C
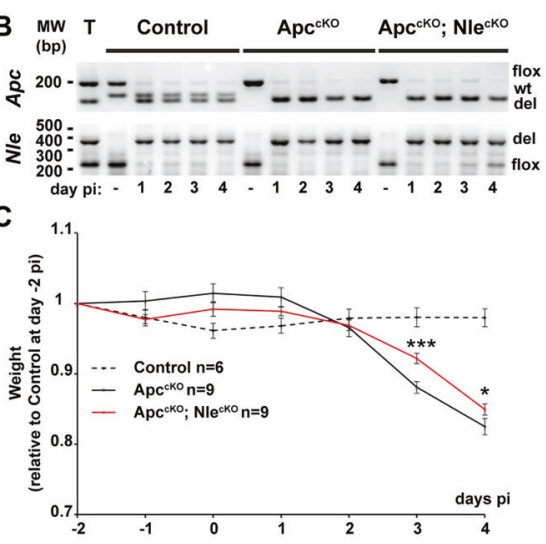

D

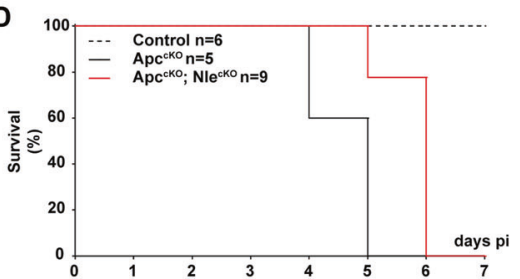

Fig. 1 Nle loss-of-function improves survival of $A p c$-deficient mice and limits crypt hyperplasia. a Scheme of tamoxifen injection and analysis. b Detection of the nonrecombined (flox) and the recombined (del) Apc (top) and Nle (bottom) alleles by PCR performed on DNA extracts from Control, $\mathrm{Apc}^{\mathrm{cKO}}$ and $\mathrm{Apc} \mathrm{cKO}^{\mathrm{cKO}} \mathrm{Nle}^{\mathrm{cKO}}$ small intestinal epithelium. Two bands of similar intensity are amplified from $A p c^{f l o x /}$ del (top) and Nle flox/del (bottom) DNA (T). The wt allele appears on the gel for Apc but not for Nle. $\mathbf{c}$ Weight curve of Control, Apc ${ }^{\mathrm{cKO}}$ and $\mathrm{Apc}^{\mathrm{cKO}}$; $\mathrm{Nle}^{\mathrm{cKO}}$ mice following tamoxifen injection. $* p<0.05$; *** $p<$

phenotype such as the ectopic paneth cells [10] and enterocyte hypertrophia were similarly observed in $\mathrm{Apc}^{\mathrm{cKO}}$; $\mathrm{Nle}^{\mathrm{cKO}}$ (Fig. S1A-C). Collectively, these data indicate that Nle loss-of-function restores crypt and villus architecture in the Apc-deficient epithelium but does not fully rescue the Apc loss-of-function clinical and histological phenotype.

\section{Nle loss-of-function attenuates proliferative compartment expansion by restoring cell cycle exit and differentiation despite Wnt pathway hyperactivation}

To verify that Wnt hyperactivation was effective in $\mathrm{Apc}^{\mathrm{cKO}}$; $\mathrm{Nle}^{\mathrm{cKO}}$ intestinal epithelia, we monitored nuclear $\beta$-catenin on small intestine sections. Accumulation of nuclear $\beta$-catenin was similarly observed in $\mathrm{Apc}^{\mathrm{cKO}}$ and $\mathrm{Apc}^{\mathrm{cKO}}$; $\mathrm{Nle}^{\mathrm{cKO}}$ intestines (Fig. 2a). Moreover, upregulation of the Wnt targets $c-M y c$ and Axin2 was found in both $\mathrm{Apc}^{\mathrm{cKO}}$ and $\mathrm{Apc}^{\mathrm{cKO}} ; \mathrm{Nle}^{\mathrm{cKO}}$ epithelia (Fig. 2b), confirming that hyperactivation of the Wnt/B-catenin pathway consecutive to Apc deficiency was not modified by Nle loss-of-function.

We then performed a $2 \mathrm{~h}$ BrdU chase to visualize proliferation in the intestinal epithelium at day 2,3 , and 4 pi
0.001 according to Student's $t$ test. d Kaplan-Meier survival curve of Control, $\mathrm{Apc}^{\mathrm{cKO}}$ and $\mathrm{Apc}^{\mathrm{cKO}} ; \mathrm{Nle}^{\mathrm{cKO}}$ mice following tamoxifen injection. The difference between $\mathrm{Apc}^{\mathrm{cKO}}$ and $\mathrm{Apc}^{\mathrm{cKO}}$; Nle $\mathrm{NKO}^{\mathrm{cK}}$ is nificant with $p<0.05$ according to Mann-Whitney Wilcoxon test. e Hematoxylin-eosin staining of intestinal epithelium sections from Control, $\mathrm{Apc}^{\mathrm{cKO}}$ and $\mathrm{Apc}^{\mathrm{cKO}} ; \mathrm{Nle}^{\mathrm{cKO}}$ small intestines at day 2 pi. Black bars indicate the crypt compartment (enlarged in the $\mathrm{Apc}^{\mathrm{cKO}}$ ). Scale bars, $50 \mu \mathrm{m}$.

(Figs. 2c and S2A). As previously reported [10, 11], proliferation in $\mathrm{Apc}^{\mathrm{cKO}}$ intestines abnormally extended beyond the histological crypt compartment. Strikingly, the proliferation pattern was restored in $\mathrm{Apc}^{\mathrm{cKO}}$; $\mathrm{Nle}^{\mathrm{cKO}}$, as BrdUpositive cells restricted to the histological crypt like in Control intestines (Fig. 2c). The proportion of BrdUpositive cells within the proliferative compartment was similar for all genotypes (Fig. 2d), suggesting that the structure of the cell cycle is not dramatically perturbed in $\mathrm{Apc}^{\mathrm{cKO}}$ and $\mathrm{Apc}^{\mathrm{cKO}}$; $\mathrm{Nle}^{\mathrm{cKO}}$ compared with Control. We observed a linear growth of their proliferative compartment overtime (Fig. S2B, C), primarily due to enlarged crypt growth in $\mathrm{Apc}^{\mathrm{cKO}}$, whereas in $\mathrm{Apc}^{\mathrm{cKO}}$; $\mathrm{Nle}^{\mathrm{cKO}}$, it was caused by histological crypt hyperplasia (Fig. S2A). Taken together, these data suggest that Nle loss-of-function reduces the expansion of the proliferative compartment consecutive to Apc loss-of-function without affecting the proliferation rate of $A p c$-deficient intestinal progenitors.

We next tested whether such attenuation could be due to a restoration of cell cycle exit by comparing the position of BrdU-positive cells after short and long periods of chase at day 2 and 3 pi. After $48 \mathrm{~h}$ of chase, while BrdU-positive cells had exited cell cycle and were found in the villus in 
A

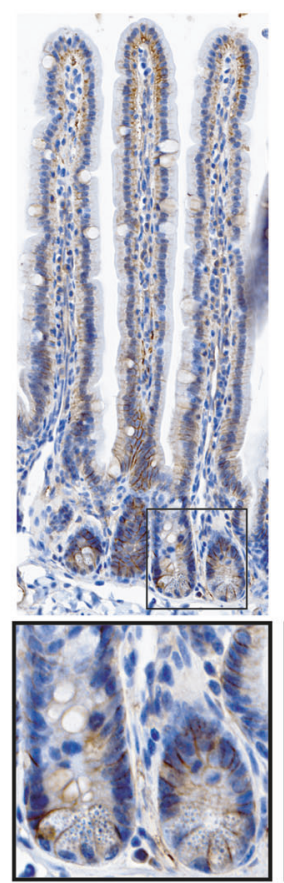

Control

C

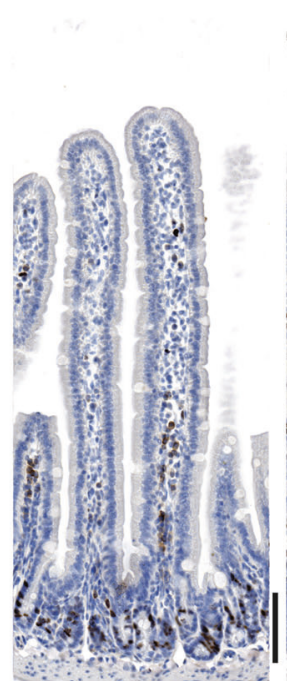

Control

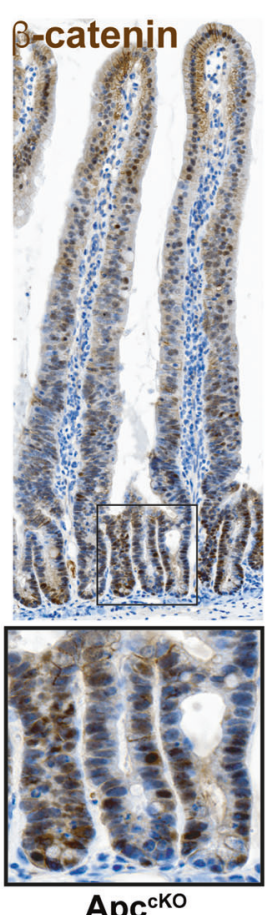

Apc $^{\mathrm{cKO}}$

BrdU

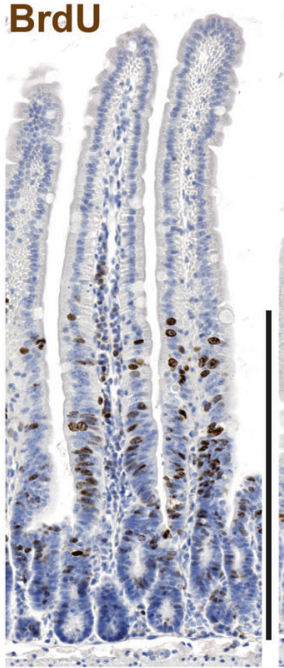

$\mathrm{Apc}^{\mathrm{cko}}$

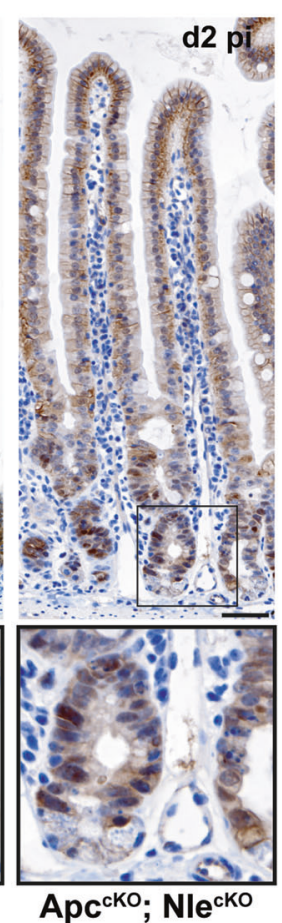

d2 pi

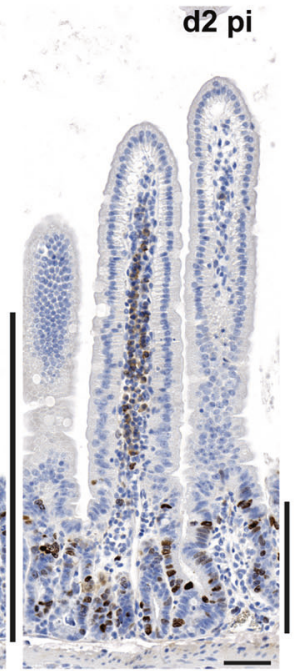

B

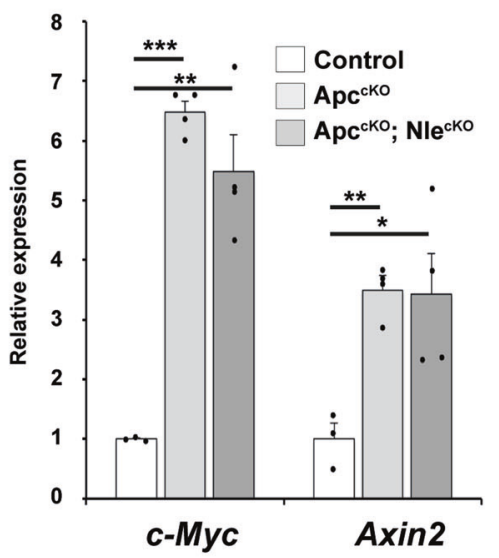

Fig. 2 Nle loss-of-function limits the expansion of the proliferative compartment expansion despite Wnt pathway hyperactivation. a $\beta$-catenin immunostaining (brown) counterstained with hematoxylin (blue) on intestinal epithelium sections from Control, Apc ${ }^{\mathrm{cKO}}$ and $\mathrm{Apc}^{\mathrm{cKO}}$; $\mathrm{Nle}^{\mathrm{cKO}}$ intestines at day 2 pi. The second lane shows magnified views of framed regions. Scale bars, $50 \mu \mathrm{m}$. b RT-qPCR performed on total RNA from Control, $\mathrm{Nle}^{\mathrm{cKO}}, \mathrm{Apc}^{\mathrm{cKO}}$ and $\mathrm{Apc}^{\mathrm{cKO}}$; $\mathrm{Nle}^{\mathrm{cKO}}$ intestinal epithelium extracts at day 2 pi. Graphs represent the mean fold changes \pm S.E.M. for Wnt transcriptional target genes $c-M y c$ and Axin2. $n \geq 3$ for each genotype. ${ }^{*} p<0.05$; ** $p<0.01$; *** $p<$ 0.001 according to Student's $t$ test. c BrdU immunostaining (brown)

Control, all $\mathrm{Apc}^{\mathrm{cKO}}$ BrdU-positive cells remained in the proliferative compartment (Figs. 3a and S3A), thereby contributing to its expansion. Of note, BrdU staining was counterstained with hematoxylin (blue) on intestinal epithelium sections from Control, $\mathrm{Apc}^{\mathrm{cKO}}$ and $\mathrm{Apc}^{\mathrm{cKO}}$; $\mathrm{Nle}^{\mathrm{cKO}}$ intestines at day $2 \mathrm{pi}$ harvested $2 \mathrm{~h}$ after BrdU injection. Black bars indicate the extension of the proliferative compartment. Scale bars, $50 \mu \mathrm{m}$. d Histogram showing the mean proportion $( \pm$ S.E.M.) of BrdU-positive cells in the proliferative compartment in Control, $\mathrm{Apc}^{\mathrm{cKO}}$ and $\mathrm{Apc}^{\mathrm{cKO}} ; \mathrm{Nle}^{\mathrm{cKO}}$ small intestines. Twenty-five transverse crypt sections were scored per mouse, $n=4$ for each genotype. The means were not significantly different among genotypes according to Mann-Whitney Wilcoxon test.

fainter in $\mathrm{Apc}^{\mathrm{cKO}}$ than in Control, suggesting that $\mathrm{Apc}^{\mathrm{cKO}}$ progenitors underwent more cell divisions than Control cells. In $\mathrm{Apc}^{\mathrm{cKO}} ; \mathrm{Nle}^{\mathrm{cKO}}$ intestine, BrdU-positive cells 


\section{A BrdU d3 pi}
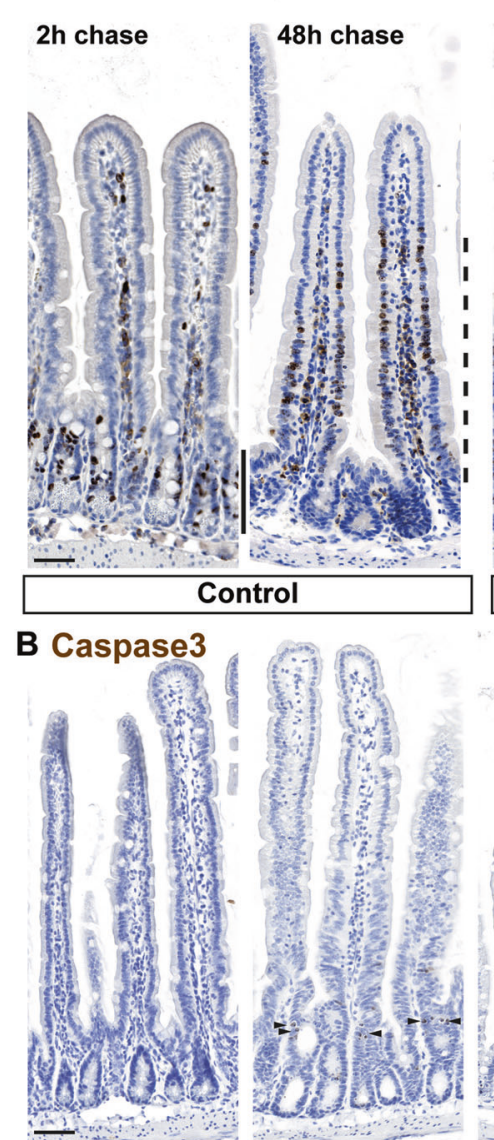

Control

D ChromoA

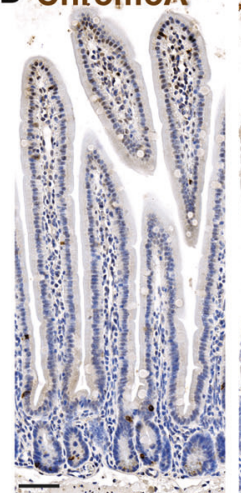

Control

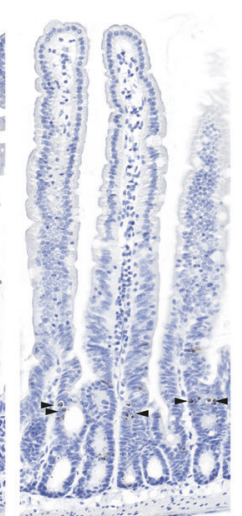

$\mathrm{Apc}^{\mathrm{ckO}}$

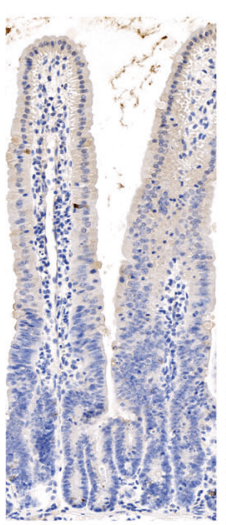

Apc $^{\mathrm{cko}}$
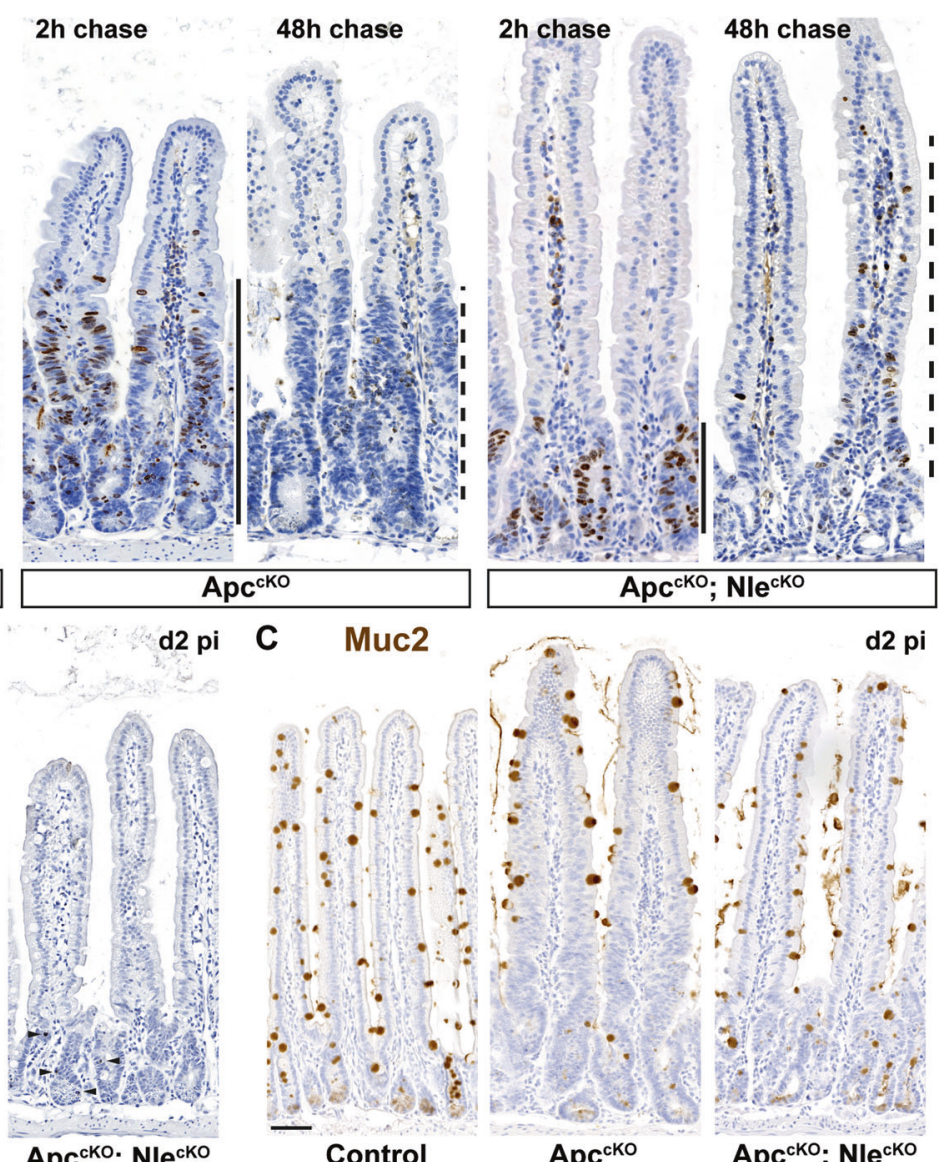

E

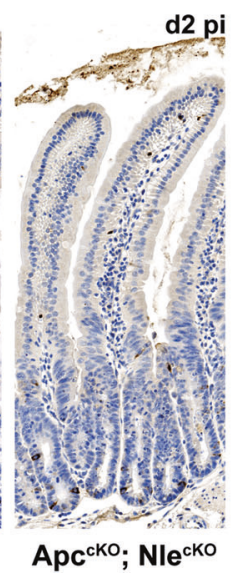

$\mathrm{Apc}^{\mathrm{cKO}} ; \mathrm{Nle}^{\mathrm{ckO}}$

Fig. 3 Nle loss-of-function restores cell cycle exit and differentiation in the $\boldsymbol{A p c}$-deficient epithelium. a BrdU immunostaining (brown) counterstained with Hematoxylin (blue) on intestinal epithelium sections from Control, $\mathrm{Apc}^{\mathrm{cKO}}$ and $\mathrm{Apc}^{\mathrm{cKO}}$; $\mathrm{Nle}^{\mathrm{cKO}}$ intestines at day $3 \mathrm{pi}$ harvested $2 \mathrm{~h}$ or $48 \mathrm{~h}$ after BrdU injection. Plain black bars indicate the proliferative compartment. Dotted black bars indicate the range of proliferative cell migration within $48 \mathrm{~h}$. Scale bars, $50 \mu \mathrm{m}$. b CleavedCaspase 3 immunostaining (brown) counterstained with Hematoxylin (blue) on intestinal epithelium sections from Control, Apc ${ }^{\mathrm{cKO}}$ and $\mathrm{Apc}^{\mathrm{cKO}}$; $\mathrm{Nle}^{\mathrm{cKO}}$ intestines at day 2 pi. Arrowheads indicate Caspase 3positive cells. Scale bars, $50 \mu \mathrm{m}$. c MUC2 immunostaining (brown) counterstained with Hematoxylin (blue) on intestinal epithelium sections from Control, $\mathrm{Apc}^{\mathrm{cKO}}$ and $\mathrm{Apc}^{\mathrm{cKO}} ; \mathrm{Nle}^{\mathrm{cKO}}$ intestines at day 2 pi. Scale

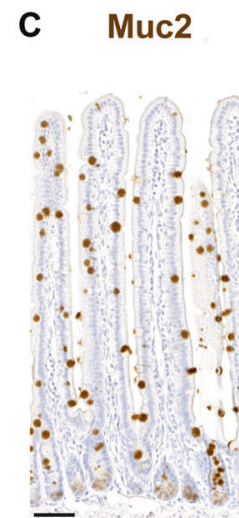

Control
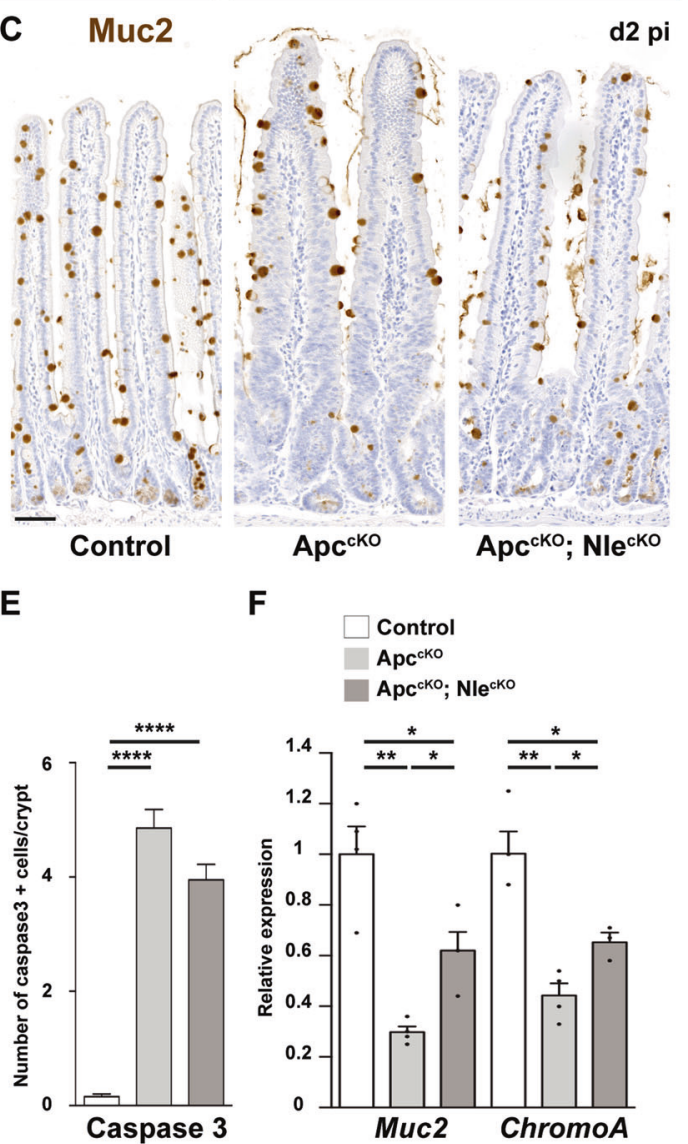

$\mathbf{F}$

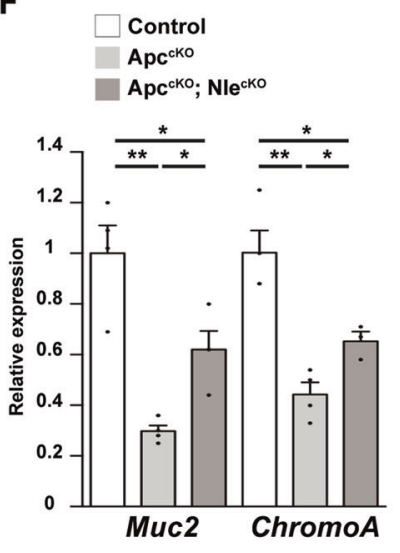

bars, $50 \mu \mathrm{m}$. d Chromogranin A immunostaining (brown) counterstained with Hematoxylin (blue) on intestinal epithelium sections from Control, $\mathrm{Apc}^{\mathrm{cKO}}$ and $\mathrm{Apc}^{\mathrm{CKO}} ; \mathrm{Nle}^{\mathrm{cKO}}$ intestines at day 2 pi. Scale bars, $50 \mu \mathrm{m}$. e Histogram showing the mean number $( \pm$ SEM $)$ of Caspase 3 -positive cells per crypt in Control, $\mathrm{Apc}^{\mathrm{cKO}}$ and $\mathrm{Apc}^{\mathrm{cKO}} ; \mathrm{Nle}^{\mathrm{cKO}}$ intestines at day 2 pi. 30 transverse crypts were scored per mouse, $n \geq 3$ for each genotype. ${ }^{*} p<0.05$ Mann-Whitney Wilcoxon test. f RT-qPCR performed on total RNA from Control, $\mathrm{Apc}^{\mathrm{cKO}}$ and $\mathrm{Apc}^{\mathrm{cKO}}$; Nle $\mathrm{NKO}^{\mathrm{c}}$ intestinal crypt extracts at day 2 pi. Graphs represent the mean fold changes \pm S.E.M. for differentiation markers Mucin 2 (Muc2) and Chromogranin A (ChromoA). $n \geq 3$ for each genotype. * $p<0.05$; ** $p<$ 0.01 according to Mann-Whitney Wilcoxon test. 
reached the villus after $48 \mathrm{~h}$ chase at day 3 pi. However, at day 2 pi, BrdU-positive cells were found in the crypt and at the boundary between the crypt and the villus (Fig. S3A, B) suggesting that though restored, cell cycle exit is delayed in $\mathrm{Apc}{ }^{\mathrm{cKO}} ; \mathrm{Nle}^{\mathrm{cKO}}$. Nle-deficiency induced a potent apoptotic response in normal intestinal progenitors [22]. Caspase 3 staining on intestinal sections showed a similar proportion of Caspase 3-positive cells in both $\mathrm{Apc}^{\mathrm{cKO}}$ and $\mathrm{Apc}^{\mathrm{cKO}}$; $\mathrm{Nle}^{\mathrm{cKO}}$ proliferative compartments (Fig. 3b, e), indicating that apoptosis is unlikely to be an important driver for the reduction of the proliferative compartment in the $\mathrm{Apc}^{\mathrm{cKO}}$; $\mathrm{Nle}^{\mathrm{cKO}}$. Finally, to evaluate the differentiation status of $\mathrm{Apc}^{\mathrm{cKO}}$ and $\mathrm{Apc}^{\mathrm{cKO}}$; $\mathrm{Nle}^{\mathrm{cKO}}$ epithelia, we performed Mucin2 and Chromogranin A immunohistochemistry (Fig. 3c, d) and Alcian Blue coloration (Fig. S3C). Enteroendocrine and goblet cells were absent from the expanded proliferative compartment of the $\mathrm{Apc}^{\mathrm{cKO}}$ as previously reported $[10,11]$. In contrast, both cell types were found in $\mathrm{Apc}{ }^{\mathrm{cKO}} ; \mathrm{Nle}^{\mathrm{cKO}}$ villi and crypts. Consistently, $M u c 2$ and ChromoA mRNA levels in $\mathrm{Apc}^{\mathrm{cKO}} ; \mathrm{Nle}^{\mathrm{cKO}}$ crypts were intermediate compared with $\mathrm{Apc}^{\mathrm{cKO}}$ and Controls (Fig. 3f). Collectively, our results indicate that Nle loss-of-function attenuates Wnt hyperactivation-driven expansion of the proliferation compartment by partially restoring the capacity of $A p c$-deficient progenitors to exit cell cycle and differentiate.

\section{Nle loss-of-function leads to ribosome biogenesis defects and p53 stabilization in the Apc-deficient epithelium}

The immediate consequences of Apc loss-of-function on ribosome biogenesis and protein synthesis in intestinal epithelium have not been described so far. No difference in the levels of nucleolar rRNA intermediates of the small (its1) and the large (its2) ribosomal subunits was observed in $\mathrm{Apc}^{\mathrm{cKO}}$ compared with Control crypts at day 2 pi (Fig. 4a, b) indicating that rRNA synthesis was not affected in Apc-deficient progenitors. Performing FISH with its1 and its2 probes, we previously showed increased ribosome biogenesis in crypts compared with villi [22]. Consistent with the invasion of proliferative cells into the villus region, FISH staining of $\mathrm{Apc}^{\mathrm{cKO}}$ showed high pre-rRNAs levels in a region corresponding to the expanded proliferative compartment (Fig. 4c). These data indicate that ribosome production in Apc-deficient proliferative cells is similar to that of Apc-proficient intestinal progenitors.

Nle loss-of-function was shown to affect large ribosomal subunit biogenesis in crypt cells [22] leading to the specific increase in its2, but not its1, levels. A similar phenotype was detected in $\mathrm{Apc}^{\mathrm{cKO}}$; $\mathrm{Nle}^{\mathrm{cKO}}$ crypts at day 2 pi (Fig. 4b, c), however its 2 accumulation was no longer restricted to crypt cells but largely extended to villi (Fig. 4c). A possible explanation for this observation would be that $\mathrm{Apc}^{\mathrm{cKO}}$;
$\mathrm{Nl}^{\mathrm{cKO}}$ progenitors, unlike $\mathrm{Nle}^{\mathrm{cKO}}$ (Villin-CreERT2 ${ }^{\mathrm{tg} / 0}$; $\left.N l e^{f l o x / n u l l}\right)$ progenitors, survived and continued to proliferate despite dysfunctional ribosome biogenesis, thereby giving rise to differentiated cells with increased nucleolar ribosomal pre-particles.

We next asked whether these defects activated a p53 stress response, as in a normal epithelium [22]. In $\mathrm{Apc}^{\mathrm{cKO}}, \mathrm{p} 53$ was transiently stabilized at day 2 pi in a few cells located at the distalmost part of the expanded proliferative compartment (Figs. 4d and S4A) consistent with previous reports [30]. In $\mathrm{Apc}^{\mathrm{cKO}}$; $\mathrm{Nle}^{\mathrm{cKO}}$, strong and persistent p53 nuclear staining was observed in most cells of the crypt and of the lower part of the villus (Figs. $4 \mathrm{~d}$ and S4B), like its2 accumulation (Fig. 4c). Importantly, robust p53 stabilization was observed in $\mathrm{Apc}^{\mathrm{cKO}} ; \mathrm{Nl}^{\mathrm{cKO}}$ progenitors in absence of cell cycle arrest (Figs. $3 \mathrm{a}$ and $\mathrm{S} 2$ ) or massive apoptotic response (Fig. 3b) contrary to $\mathrm{Nle}^{\mathrm{cKO}}$ crypt cells [22]. Collectively, our data show that Nle loss-offunction leads to defective ribosome biogenesis and p53 stabilization in Apc-deficient progenitor cells without triggering the cell cycle arrest and apoptotic responses normally observed in Apc-proficient cells.

\section{The double mutant transcriptome is essentially the sum of single mutant transcriptomes}

We performed RNAseq on Control, $\mathrm{Nle}^{\mathrm{cKO}}, \mathrm{Apc}^{\mathrm{cKO}}$, and $\mathrm{Apc}^{\mathrm{cKO}}$; $\mathrm{Nle}^{\mathrm{cKO}}$ crypts at day 1 and 2 pi (Fig. 5; Supplementary Table S3). Principal component analysis clearly distinguished samples according to their genotype (Fig. 5a), with PC1 (58.79\% of the variance) and PC2 (12.77\% of the variance) segregating the samples according to the $A p c$ or Nle genotype, respectively. $\mathrm{Apc}^{\mathrm{cKO}} ; \mathrm{Nle}^{\mathrm{cKO}}$ samples were undistinguishable from $\mathrm{Apc}^{\mathrm{cKO}}$ according to $\mathrm{PC} 1$ and from $\mathrm{Nle}^{\mathrm{cKO}}$ according to $\mathrm{PC} 2$, indicating that $\mathrm{Apc}{ }^{\mathrm{cKO}} ; \mathrm{Nle}^{\mathrm{cKO}}$ is essentially the linear combination of $\mathrm{Nl}^{\mathrm{cKO}}$ and $\mathrm{Apc}^{\mathrm{cKO}}$. Using K-means clustering, we found that the 15,115 genes expressed in our dataset could be spread into 10 clusters with distinct gene expression variation patterns (Fig. 5b; Supplementary Table S4). Strikingly, the vast majority of the genes had the same expression pattern in $\mathrm{Apc}^{\mathrm{cKO}}$; $\mathrm{Nle}^{\mathrm{cKO}}$ as in $\mathrm{Apc}^{\mathrm{cKO}}$, with only 4 clusters $(6,7,9$, and 10$)$ comprising $3259(21 \%)$ genes that were differentially regulated in $\mathrm{Apc}^{\mathrm{cKO}}$; $\mathrm{Nle}^{\mathrm{cKO}}$ compared with $\mathrm{Apc}^{\mathrm{cKO}}$ samples. Gene expression pattern varied little according to the timing.

To distinguish additive from nonadditive interactions between the two mutations, we performed a model-based analysis where timings were considered separately (Fig. 5c, d). Considering all samples at a given time point, a "Nle-related," an "Apc-related" fold change and an interaction term describing the deviation of the double mutant from a linear combination of the two mutants were 
A
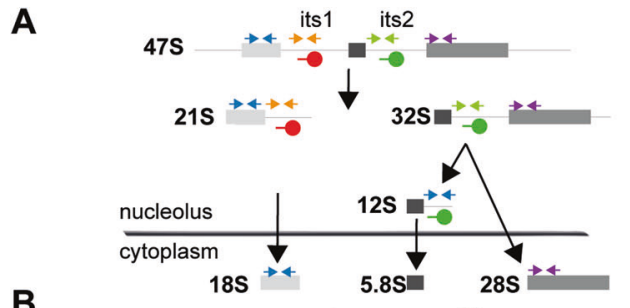

B $18 \mathrm{~S}$

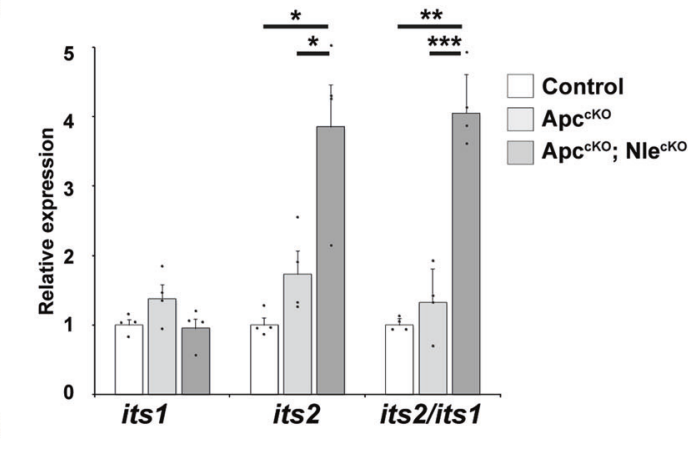

D

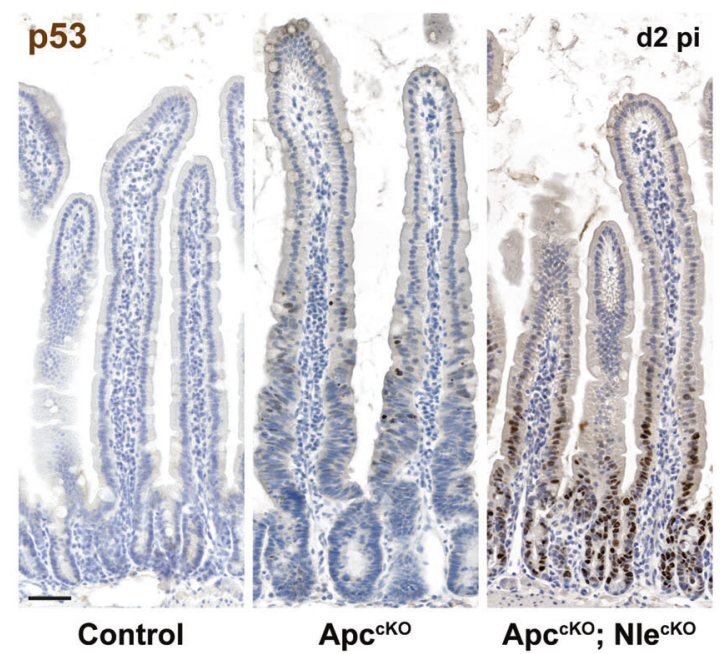

Fig. 4 Nle loss-of-function leads to ribosome biogenesis defects and p53 stabilization in the $A p c$-deficient epithelium. a Simplified diagram illustrating the main steps of ribosome biogenesis in eukaryotic cells. Blue arrows represent the primers used to measure the levels of ribosomal RNAs by RT-qPCR. FISH probes used to detect its1 (red) and its2 (green) sequences from precursors of the small and large ribosomal subunits, respectively, are indicated. b RT-qPCR performed on total $\mathrm{RNA}$ from Control, Apc ${ }^{\mathrm{cKO}}$ and $\mathrm{Apc}^{\mathrm{CKO}} ; \mathrm{Nle}^{\mathrm{cKO}}$ intestinal crypt extracts at day 2 pi. Graphs represent the mean fold changes \pm S.E.M. for the

calculated for each gene. Examining cases where the effects of the double mutant were either an independent combination of both, or exhibited a dependence, we distinguished eight gene categories (Fig. 5c; Supplementary Table S5), four of which encompassed genes that were subject to nonadditive interactions (i.e., have a " $\mathrm{D}$ " term). Consistent with the principal component analysis, Apc loss-of-function was largely dominant compared with Nle loss-of-function ( $91 \%$ vs $38 \%$ of misregulated genes at day 2 pi) (Fig. 5 d). Besides genes that were either unaffected in all genotypes $([-|-|-])$ and those affected only by Apc or Nle loss-of-

C

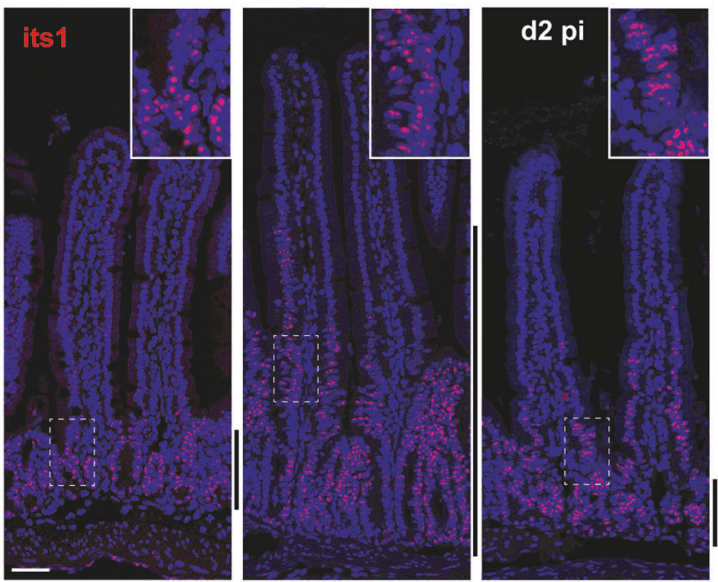

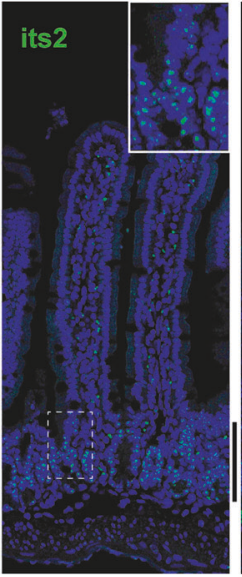

Control

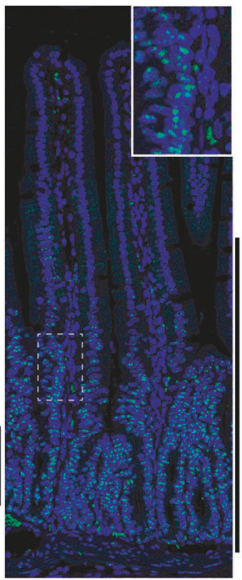

$\mathrm{Apc}^{\mathrm{cko}}$

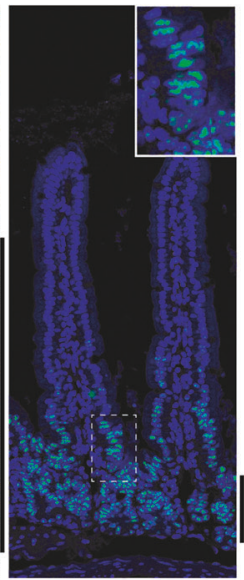

$\mathrm{Apc}^{\mathrm{cKO}} ; \mathrm{Nle}^{\mathrm{ckO}}$ different amplicons. $n=4$ for each genotype. $* p<0.05$; $* p<0.01$; $* * * p<0.001$ according to Student's $t$ test. c FISH for its1 (red) or its2 (green) counterstained with Hoechst (blue) on intestinal epithelium sections from Control, $\mathrm{Apc}^{\mathrm{cKO}}$ and $\mathrm{Apc}^{\mathrm{cKO}}$; $\mathrm{Nl}^{\mathrm{cKO}}$ intestines at day 2 pi. Scale bars, $50 \mu \mathrm{m}$. Lateral bars indicate the position of the crypt domain for Control and $\mathrm{Apc}^{\mathrm{cKO}}$; $\mathrm{Nle}^{\mathrm{cKO}}$ and of the enlarged crypt-like compartment for $\mathrm{Apc}^{\mathrm{cKO}}$. d p53 immunostaining (brown) counterstained with Hematoxylin (blue) on intestinal epithelium sections from Control, $\mathrm{Apc}^{\mathrm{cKO}}$ and $\mathrm{Apc}^{\mathrm{cKO}} ; \mathrm{Nle}^{\mathrm{cKO}}$ intestines at day 2 pi. Scale bars, $50 \mu \mathrm{m}$.

function ([A|-|-] and $[-|\mathrm{N}|-])$, a minority of genes was subject to either additive ([AINI-], 15\% of misregulated genes at day 2 pi) or nonadditive interactions ([-I-|D], [-|N| $\mathrm{D}],[\mathrm{Al}-\mathrm{ID}]$, and [AINID], $14 \%$ of misregulated genes at day 2 pi) (Fig. 5d). Gene and phenotype ontology enrichment analysis (Figs. 5e and S5) showed that Apc or Nle loss-offunction upregulated genes involved in ribosome biogenesis in an additive manner (Fig. 5e, [AINI-]). Interestingly, the sub-cluster of genes that are expressed at intermediate levels in $\mathrm{Apc}^{\mathrm{cKO}} ; \mathrm{Nle}^{\mathrm{cKO}}$ due to the additive effect of Apc-related upregulation and Nle-related downregulation is significantly 


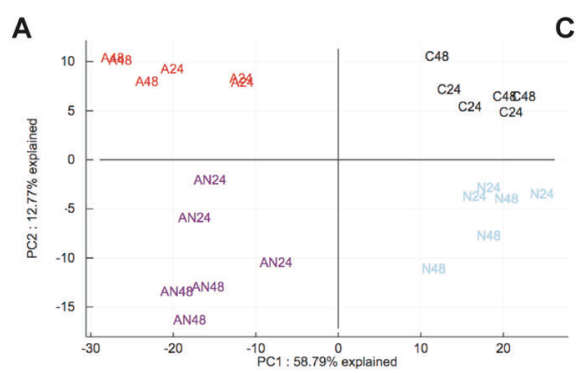

$c$

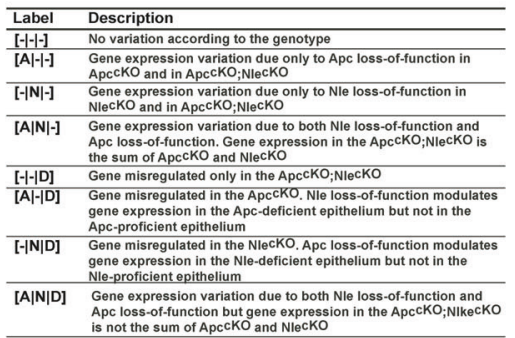

D

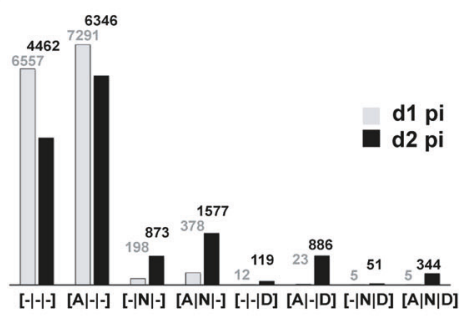

B

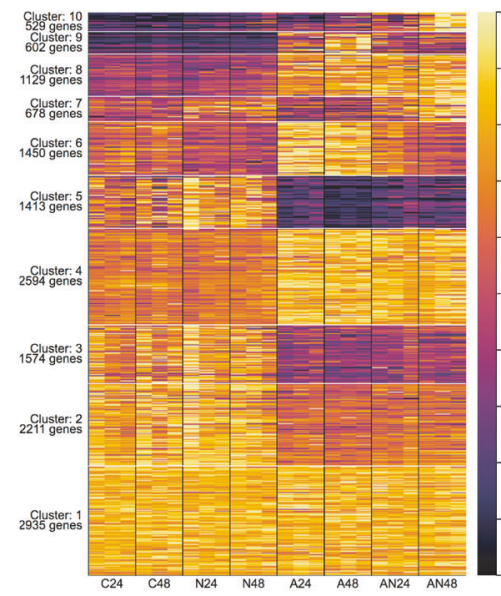

E

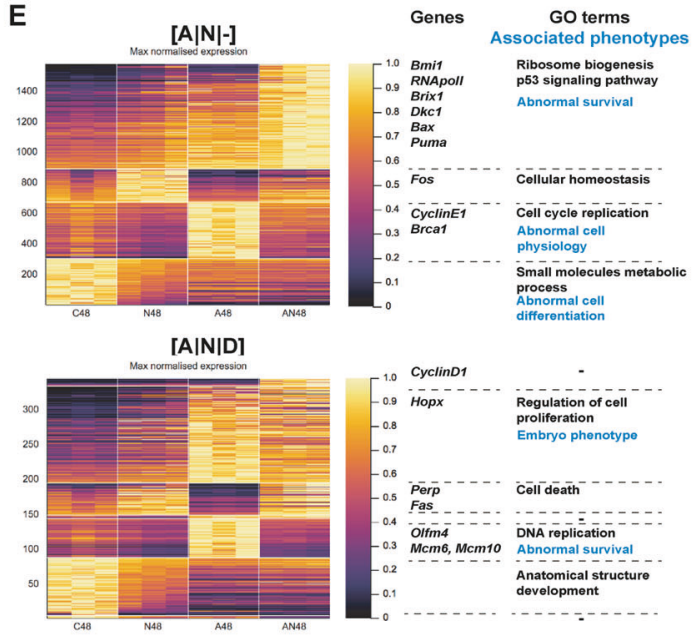

$F$

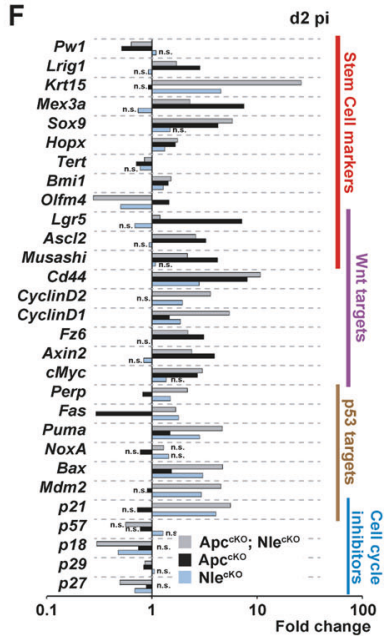

Fig. 5 The double mutant transcriptome is the sum of simple mutant transcriptomes. a Principal Component Analysis (PCA) of the samples. PC2 is plotted against $\mathrm{PC} 1 . \mathrm{Apc}^{\mathrm{cKO}}(\mathrm{A})$ and $\mathrm{Apc} \mathrm{cKO}^{\mathrm{CO}}$; $\mathrm{Nle}^{\mathrm{cKO}}(\mathrm{AN})$ are distinguishable from Control (c) and $\mathrm{Nle}^{\mathrm{cKO}}(\mathrm{N})$ according to $\mathrm{PC} 1$, whereas $\mathrm{N}$ and $\mathrm{AN}$ are distinguishable from $\mathrm{C}$ and A according to $\mathrm{PC} 1$, meaning that $\mathrm{PC} 1$ corresponds to Apc loss-offunction and PC2 corresponds to Nle loss-of-function. b K-means clustering on all genes normalized by their maximum expression among the samples. c List and description of the eight theoretical categories of genes according to the model-based analysis. - no: change; $\mathrm{N}$ : change in all $\mathrm{Nle}^{\mathrm{cKO}}$ samples including double mutant ones; A: change in all $\mathrm{Apc}^{\mathrm{cKO}}$ samples including double mutant ones; and D: change in double mutant $\mathrm{Apc}^{\mathrm{cKO}}$; $\mathrm{Nle}^{\mathrm{cKO}}$ different from that

enriched in genes involved in cell cycling and proliferation (Fig. 5e, [AINI-]). Overall, hypothesizing that the observed phenotypic differences arises from differential gene regulation at the transcriptional level, these results suggest that the phenotype of the $\mathrm{Apc}^{\mathrm{cKO}} ; \mathrm{Nl}^{\mathrm{cKO}}$ essentially results from additive gene-by-gene effects of Apc and Nle loss-offunction rather than signaling pathway transcriptional activation or shutdown.

We next examined a few sets of genes whose differential expression might be relevant to the $\mathrm{Apc}^{\mathrm{cKO}}$; $\mathrm{Nl}^{\mathrm{cKO}}$ phenotype (Fig. 5f). Upregulation of cell cycle inhibitor genes in $\mathrm{Apc}^{\mathrm{cKO}} ; \mathrm{Nle}^{\mathrm{cKO}}$ progenitors compared with $\mathrm{Apc}{ }^{\mathrm{cKO}}$ might explain their enhanced capacity to stop proliferating. However, $p 21$ was the only cell cycle inhibitor upregulated in $\mathrm{Apc}^{\mathrm{cKO}} ; \mathrm{Nle}^{\mathrm{cKO}}$ to levels similar to $\mathrm{Nle}^{\mathrm{cKO}}$. This was likely due to $\mathrm{p} 53$ activation since $p 21$ is a well-known p53 target. Other p53 targets were equally upregulated in predicted by the additive combination of $\mathrm{N}$ and $\mathrm{A}$. (d) Histogram showing the distribution of genes among the eight categories at day 1 pi and day 2 pi. The number of genes assigned to each category is indicated at both timings. e Genes in the [AINI-] and [AINID] categories were separated into clusters by the direction of the A, N and D fold changes at day 2 pi. Gene number is plotted on the left of each heatmap. For each cluster, genes relevant to the analyzed phenotypes are indicated, as well as the most significantly enriched gene (black) and phenotype (blue) ontology terms from MouseMine. f Histograms showing the expression variation at day 2 pi of some cell cycle inhibitor-coding mRNAs (blue), p53 transcriptional targets (red), Wnt transcriptional targets (purple) and transcripts enriched in ISCs (red). ns, fold change not significant.

$\mathrm{Apc}^{\mathrm{cKO}} ; \mathrm{Nle}^{\mathrm{cKO}}$ and $\mathrm{Nle}^{\mathrm{cKO}}$, including those that were downregulated in the $\mathrm{Apc}^{\mathrm{cKO}}$ (Fas and Perp). Thus, Wnt hyperactivation does not dramatically impact $p 53$ transcriptional response. Conversely, most Wnt targets were similarly upregulated in $\mathrm{Apc}^{\mathrm{cKO}} ; \mathrm{Nl}^{\mathrm{cKO}}$ and $\mathrm{Apc}^{\mathrm{cKO}}$, suggesting that Nle loss-of-function only marginally modulates the Wnt hyperactivation transcriptional response. Finally, intestinal stem cell marker expression in $\mathrm{Apc}^{\mathrm{cKO}} ; \mathrm{Nl}^{\mathrm{cKO}}$ resulted from either additive (Ascl2, Sox9, Tert, Pwl, and Bmil) or nonadditive (Olfm4, Lgr5, Mex3a, Lrig1, Krt15, and Hopx) effects. Strikingly, Nle loss-of-function attenuated Wnt hyperactivation-driven Lgr5 upregulation but also participated to the synergic upregulation of the reserve stem cell markers Krt15 and, to a lesser extend Hopx and Bmil. This suggests that the reserve intestinal stem cell population might be particularly stimulated in the $\mathrm{Apc}^{\mathrm{cKO}}$; $\mathrm{Nle}^{\mathrm{cKO}}$ intestine. 
Nle loss-of-function leads to a reduction of mature rRNAs and protein synthesis activity in Apc-deficient crypts

We next asked whether alterations in ribosome content and protein synthesis activity could contribute to the phenotype. We first quantified the levels of mature rRNAs (18S and 28S) by RT-qPCR (Fig. 4a). No difference in rRNA levels was observed in Apc ${ }^{\mathrm{cKO}}$ crypts compared with Control at day 2 pi (Fig. 6a) indicating that, like pre-rRNA, ribosome content was not affected in Apc-deficient progenitors. We also monitored protein synthesis by puromycin incorporation in vivo [22]. Surprisingly, quantification of puromycylated nascent chains after a short in vivo pulse of puromycin revealed an increased number of active ribosomes in Apc-deficient progenitors compared with the control at day 2 and day 3 pi (Figs. 6b, c and S6). Taken together with the aforementioned analyses of pre-rRNA levels, these data indicate that upregulation of protein synthesis, but not ribosome biogenesis, is an early feature of Apc-deficient progenitors.

Interestingly, contrary to the $\mathrm{Nle}^{\mathrm{cKO}}$, mature rRNA levels were significantly decreased in $\mathrm{Apc}{ }^{\mathrm{cKO}} ; \mathrm{Nl}^{\mathrm{cKO}}$ crypts (Fig. 6a). It can be hypothesized that progenitor survival and proliferation despite ribosome biogenesis defects in the $\mathrm{Apc}^{\mathrm{cKO}} ; \mathrm{Nle}^{\mathrm{cKO}}$ gives rise to cells with decreased ribosome content. Strikingly, the number of active ribosomes in $\mathrm{Apc}^{\mathrm{cKO}} ; \mathrm{Nle}^{\mathrm{cKO}}$ crypt cells was significantly reduced compared to Apc ${ }^{c K O}$ and similar to control crypt cells (Figs. 6b, $\mathrm{c}$ and S6). Altogether, these data suggest that, in the context of Apc-deficient intestinal epithelium, Nle loss-of-function leads to a reduction of ribosome content consecutive to ribosome biogenesis defects, which, in turn, decreases translational activity of $A p c$-deficient progenitors to controllike levels. Such impairment of translation stimulation might contribute to induce cell cycle exit in $\mathrm{Apc}^{\mathrm{cKO}} ; \mathrm{Nle}^{\mathrm{cKO}}$ progenitors.

\section{Wnt hyperactivation prevents $\mathrm{p} 53$-induced rapid depletion of intestinal stem and progenitor cells in Nle-deficient crypts}

We then examined the fate of intestinal stem cells in $\mathrm{Apc}^{\mathrm{cKO}}$; $\mathrm{Nl}^{\mathrm{cKO}}$ mice. RT-qPCR confirmed the transcriptomic data as $\operatorname{Lgr} 5$ was upregulated in the $\mathrm{Apc}^{\mathrm{cKO}}$ and restored to control levels in the $\mathrm{Apc}^{\mathrm{cKO}} ; \mathrm{Nle}^{\mathrm{cKO}}$ at day $2 \mathrm{pi}$, whereas Olfm 4 was downregulated in both $\mathrm{Nle}^{\mathrm{cKO}}$ and

A
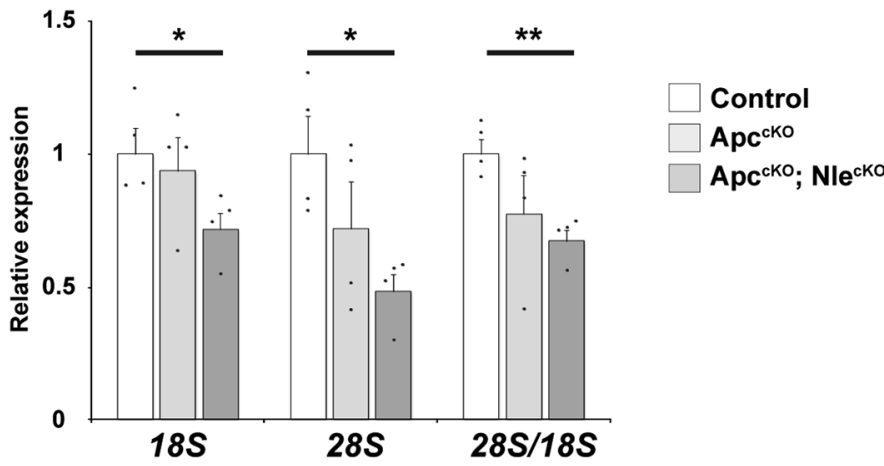

$18 S$

$28 S$

28S/18S

B

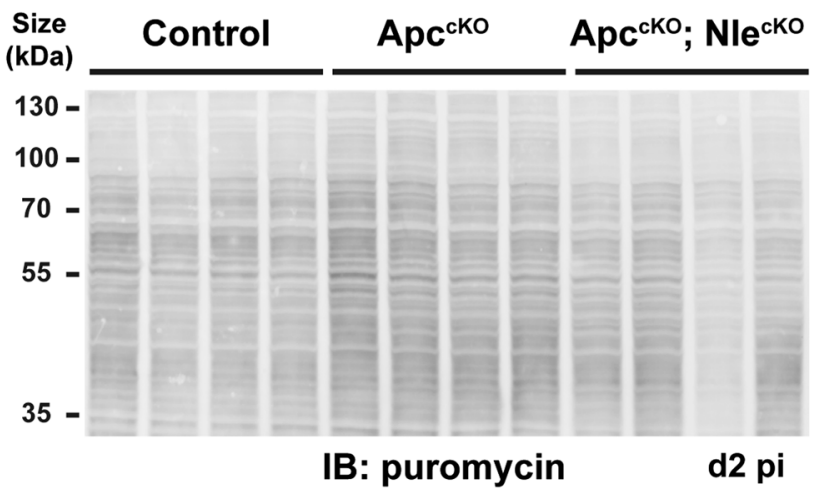

C

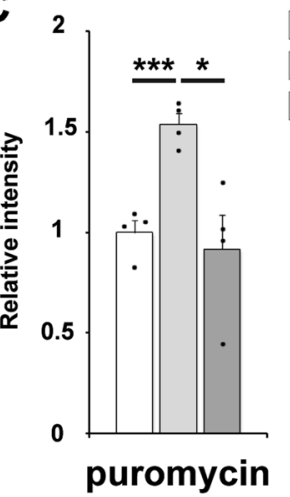

Control

Apc ${ }^{\text {cko }}$

$\mathrm{Apc}^{\mathrm{ckO}} ; \mathrm{Nle}^{\mathrm{ckO}}$
Fig. 6 Nle loss-of-function causes a diminution of mature rRNA levels and global protein synthesis in the $A p c$-deficient epithelium. a RT-qPCR for $18 \mathrm{~S}$ and $28 \mathrm{~S}$ rRNA performed on total RNA from Control, $\mathrm{Apc}^{\mathrm{cKO}}$ and $\mathrm{Apc}^{\mathrm{cKO}}$; $\mathrm{Nle}^{\mathrm{cKO}}$ intestinal crypt extracts at day 2 pi. Graphs represent the mean fold changes \pm S.E.M. for the different amplicons. $n=4$ for each genotype. ${ }^{*} p<0.05 ; * * p<0.01$ according to
Student's $t$ test. b Anti-puromycin immunoblotting of protein extracts for identical number of crypts cells from Control, Apc ${ }^{\mathrm{cKO}}$ and $\mathrm{Apc}^{\mathrm{cKO}}$; $\mathrm{Nle}^{\mathrm{cKO}}$ intestines at day 2 pi. c Histogram showing the mean normalized signal intensity \pm S.E.M from the immunoblot shown in (b). $n=4$ for each genotype. $* p<0.05$ according to Mann-Whitney Wilcoxon test. 
$\mathrm{Apc}^{\mathrm{cKO}}$; $\mathrm{Nl}^{\mathrm{cKO}}$ compared with Control (Fig. 7a). In situ hybridization indicated that, as expected, Olfm 4 expression confined to cells at the crypt bottom in Control, extended upward in $\mathrm{Apc}^{\mathrm{cKO}}$ and was markedly decreased in $\mathrm{Nle}^{\mathrm{cKO}}$ (Fig. 7b). In $\mathrm{Apc}^{\mathrm{cKO}}$; $\mathrm{Nle}^{\mathrm{cKO}}$, Olfm 4 staining was similar to $\mathrm{Apc}^{\mathrm{cKO}}$ but varied from crypt to crypt and was generally fainter than both Control and $\mathrm{Apc}^{\mathrm{cKO}}$. Interestingly, nuclear p53 protein was detected in crypt base columnar cells, recognizable by their shape and location at the crypt base, at every tested time point (Fig. 7c) suggesting that, like progenitors, Apc-deficient stem cells were less sensitive to ribosome biogenesis defects and p53 activation than $A p c$ proficient stem cells. Indeed, contrary to $\mathrm{Nle}^{\mathrm{cKO}}$, proliferating $\mathrm{CBCs}$ were present at the bottom of $\mathrm{Apc}^{\mathrm{cKO}}$; $\mathrm{Nle}^{\mathrm{cKO}}$ crypts (Fig. 7d). Collectively, these data show that intestinal stem and progenitor cells are maintained in $\mathrm{Apc}^{\mathrm{cKO}} ; \mathrm{Nle}^{\mathrm{cKO}}$ mice despite defective ribosome biogenesis and robust p53 activation.
A

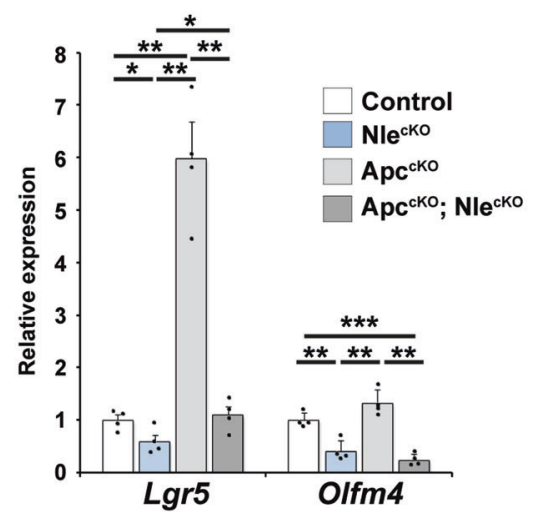

C $\mathrm{p} 53$

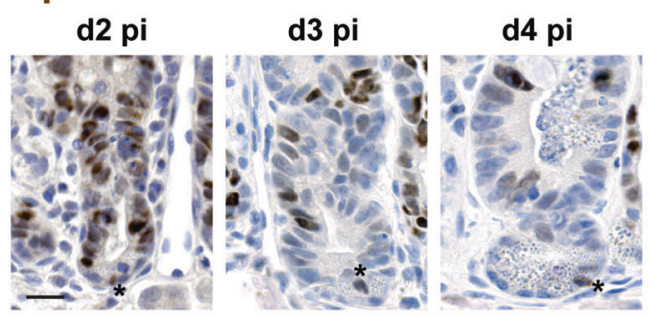

Apc $^{\text {cko; }}$ Nle
B Olfm4 ISH

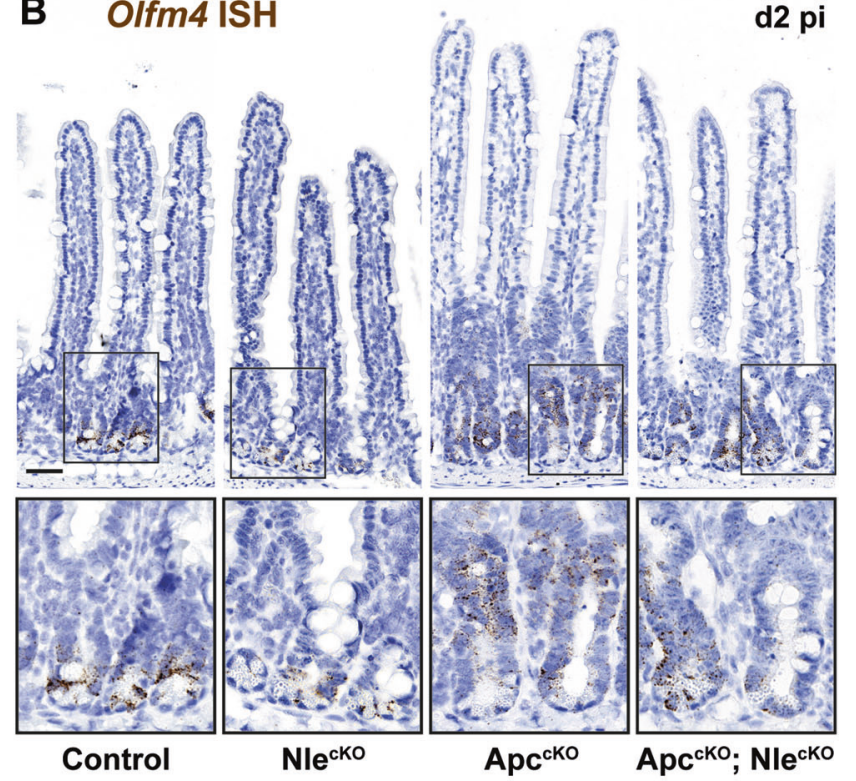

D BrdU 2h chase Control

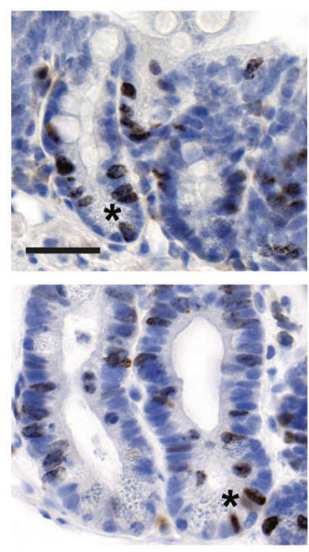

Apc ${ }^{\text {cko }}$

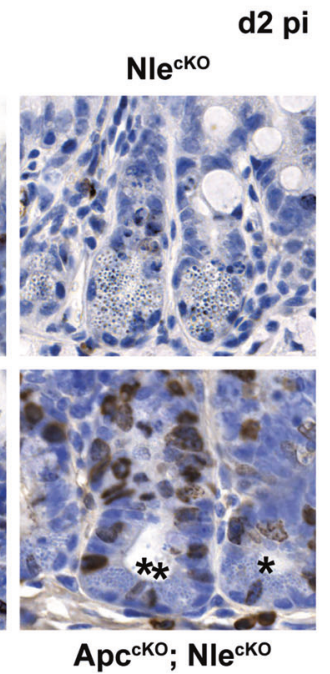

d2 pi

Fig. 7 Apc loss-of-function attenuates stem cell loss following Nle deletion. a RT-qPCR performed on total RNA from Control, Nle ${ }^{\text {cKO }}$, $\mathrm{Apc}^{\mathrm{cKO}}$ and $\mathrm{Apc}^{\mathrm{cKO}} ; \mathrm{Nle}^{\mathrm{cKO}}$ intestinal crypt extracts at day 2 pi. Graphs represent the mean fold changes \pm S.E.M. for ISC markers Lgr5 and Olfm4. $n=4$ for each genotype. $* p<0.05 ; * * p<0.01$; ***p $<001$ according to Student's $t$ test. b In situ hybridization for Olfm4 mRNA (brown) counterstained with Hematoxylin (blue) on intestinal epithelium sections from Control, $\mathrm{Nle}^{\mathrm{cKO}}, \mathrm{Apc}^{\mathrm{cKO}}$, and $\mathrm{Apc}^{\mathrm{cKO}} ; \mathrm{Nle}^{\mathrm{cKO}}$ intestines.

The second lane shows magnified views of framed regions. Scale bars, $50 \mu \mathrm{m}$. c p53 immunostaining (brown) counterstained with Hematoxylin (blue) on crypt sections from $\mathrm{Apc}^{\mathrm{cKO}} ; \mathrm{Nl}^{\mathrm{cKO}}$ intestines at days 2, 3 and 4 pi. Asterisks indicate p53-positive CBCs. Scale bars, $25 \mu \mathrm{m}$. d BrdU immunostaining (brown) counterstained with Hematoxylin (blue) on crypt sections from Control, $\mathrm{Nle}^{\mathrm{cKO}}, \mathrm{Apc}^{\mathrm{cKO}}$, and $\mathrm{Apc}^{\mathrm{cKO}}$; $\mathrm{Nle}^{\mathrm{cKO}}$ intestines at day 2 pi harvested $2 \mathrm{~h}$ after BrdU injection. Asterisks indicate BrdU-positive CBCs. Scale bars, $25 \mu \mathrm{m}$. 
To confirm this point, we derived organoids from control, $\mathrm{Nl}^{\mathrm{cKO}}, \mathrm{Apc}^{\mathrm{cKO}}$, and $\mathrm{Apc}^{\mathrm{cKO}} ; \mathrm{Nl}^{\mathrm{cKO}}$ crypts harvested at day 1 pi (Fig. 8a, b). Contrary to $\mathrm{Nle}^{\mathrm{cKO}}$ crypts, $\mathrm{Apc}^{\mathrm{cKO}} ; \mathrm{Nle}^{\mathrm{cKO}}$ crypts grew into organoids at the same rate as Control (Fig. 8a). Of note, $\mathrm{Apc}^{\mathrm{cKO}}$; $\mathrm{Nl}^{\mathrm{cKO}}$ organoids grew as spheroids like $\mathrm{Apc}^{\mathrm{cKO}}$ (Fig. 8b). Overtime, Apc ${ }^{\mathrm{cKO}} ; \mathrm{Nle}^{\mathrm{cKO}}$ organoids were progressively populated by Nle-proficient cells that had escaped recombination at the Nle locus. This, together with the fact that continuous Cre induction is detrimental to organoid growth [31], prevented us to assess the behavior of $\mathrm{Apc}^{\mathrm{cKO}} ; \mathrm{Nle}^{\mathrm{cKO}}$ organoids at later time points. In order to highlight possible increased resistance to p53 activation of $\mathrm{Apc}^{\mathrm{cKO}}$ stem and progenitor cells compared with Control, we cultured organoids with increasing doses of nutlin-3, a small compound that activates p53 through inhibition of Mdm2. $\mathrm{Apc}^{\mathrm{cKO}}$ organoids were more resistant to nutlin-3 treatment than Control, as viability of Control was strongly reduced at 5 $\mu \mathrm{M}$ nutlin-3 while that of $\mathrm{APC}^{\mathrm{CKO}}$ organoids was almost unaffected (Fig. 8d) despite robust p53 stabilization (Fig. S7B). Collectively, these results show that $\mathrm{Apc}^{\mathrm{cKO}} ; \mathrm{Nl}^{\mathrm{cKO}}$ intestinal stem and progenitor cells display enhanced survival to p53 activation.
A

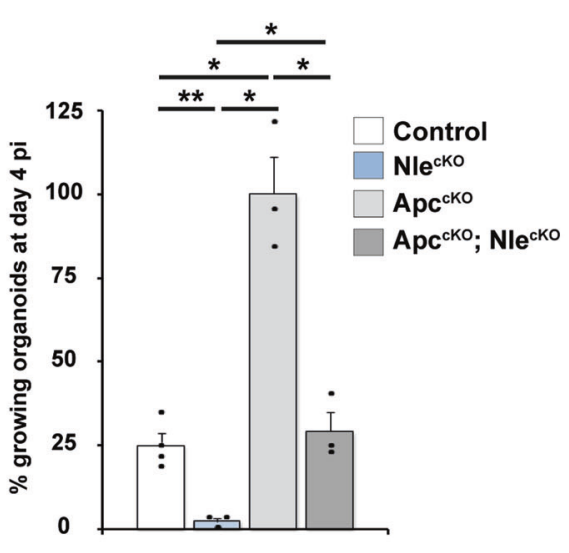

C

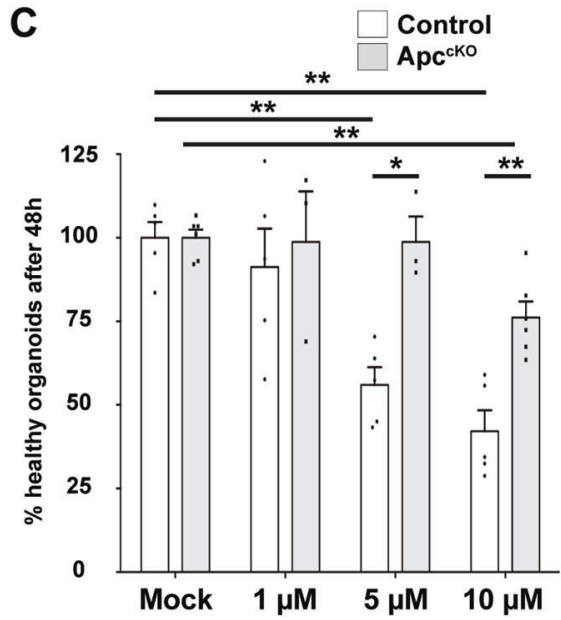

Fig. $8 \mathrm{Apc}^{\mathrm{cKO}}$ intestinal organoids show increased tolerance to Nledeficiency and p53 stabilization. a Histogram showing the mean percentage $( \pm$ S.E.M.) of organoid formation and survival at day 4 pi from an initial culture of 400 crypts per well from Control, Nle ${ }^{\mathrm{cKO}}$, $\mathrm{Apc}^{\mathrm{cKO}}$ and $\mathrm{Apc}^{\mathrm{cKO}}$; $\mathrm{Nle}^{\mathrm{cKO}}$ intestines harvested at day 1 pi. $n \geq 3$ experiments for each genotype. $\mathbf{b}$ Pictures of organoids obtained from Control, $\mathrm{Nle}^{\mathrm{cKO}}, \mathrm{Apc}^{\mathrm{cKO}}$, and $\mathrm{Apc}^{\mathrm{CKO}}$; Nle ${ }^{\mathrm{cKO}}$ crypts. The top lane shows a global view of a well for each genotype at day 4 pi. The middle lane (resp. bottom lane) shows the morphology of organoids of the different genotypes at day 4 (resp. 6) pi. c Histogram showing the mean percentage $( \pm$ S.E.M.) of healthy organoids after $48 \mathrm{~h}$ culture

D

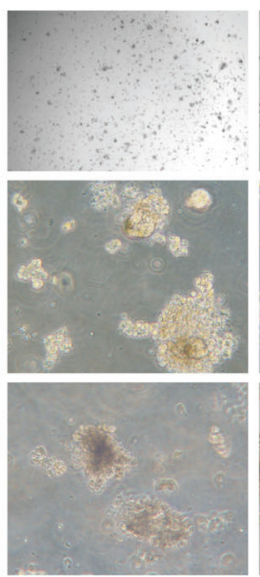

Nle ${ }^{\mathrm{ckO}}$
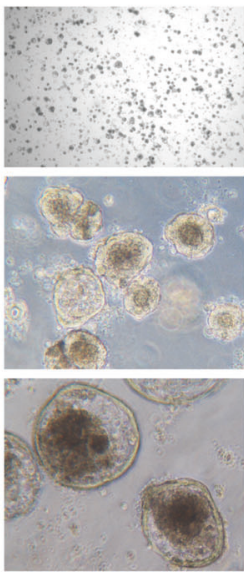

Apc cko
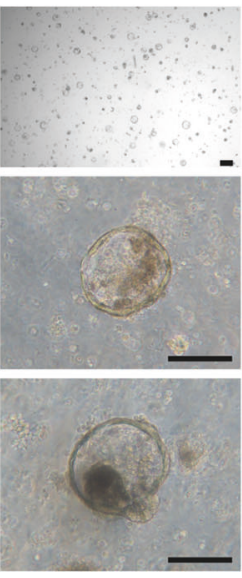

Apc ${ }^{\text {cko }} ; \mathrm{Nle}^{\text {cko }}$

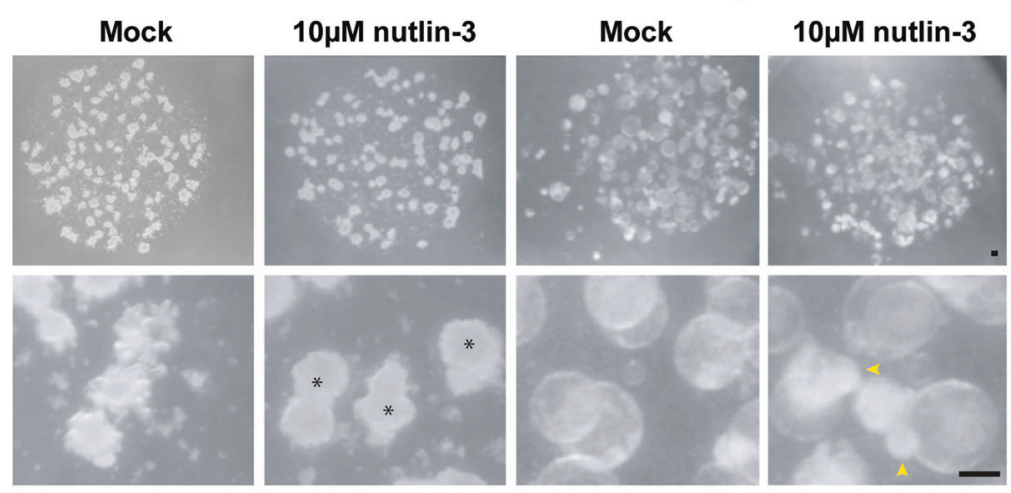

with various concentration of nutlin-3. d Pictures of Control and $\mathrm{Apc}^{\mathrm{cKO}}$ organoids after $48 \mathrm{~h}$ in mock and $10 \mu \mathrm{M}$ nutlin-3 culture conditions. Under nutlin-3 treatment, many Control organoids displayed abnormal morphology (star) with absence of budding, swelling and increased opacity likely resulting from increased accumulation of dead cells in the lumen while some $\mathrm{Apc}^{\mathrm{cKO}}$ spheroids were of irregular shape, opaque and collapsed (arrowhead). Such unhealthy structures were usually degenerating in the following days of culture. $* p<0.05$; ${ }^{* *} p<0.01$ according to Mann-Whitney Wilcoxon test. Scale bars, $150 \mu \mathrm{m}$. 


\section{Discussion}

Colorectal cancers, like many cancers, are characterized by increased ribosome biogenesis and protein translation $[32,33]$. High expression of pre-rRNA is associated with poor prognosis in colorectal cancer [34] and increased translational elongation is key for intestinal tumorigenesis [35]. Interestingly, oxaliplatin, a drug commonly used to treat colorectal cancers, was shown to affect ribosome biogenesis and trigger p53 induction and, consistent with this, cancer cells sensitive to oxaliplatin display higher ribosome biogenesis and mRNA translation rates [36]. Here, we showed that in vivo gut epithelium-specific inhibition of ribosome biogenesis strongly attenuates the expansion of the proliferative compartment during tumor initiation.

Inactivation of some key target genes of the Wnt/ $\beta$ catenin pathway such as $c-M y c$ [12], cyclinD2 [37] and Fakl [38] or of the chromatin remodeling factor $\mathrm{Brgl}$ [39] were also shown to dampen the expansion of the proliferative compartment in $\mathrm{Apc}^{\mathrm{cKO}}$ mice. In all these situations, dampening was accompanied by a marked alteration of the Wnt hyperactivation transcriptional signature. In contrast, Nle loss-of-function only marginally modifies the transcriptomic response to Apc loss-offunction. The partial rescue of $\mathrm{Apc}^{\mathrm{cKO}}$; $\mathrm{Nle}^{\mathrm{cKO}}$ mice phenotype is thus rather due to the compensation between the antagonistic effects of Wnt-driven tumorigenesis and ribosome biogenesis inhibition.

In $\mathrm{Apc}^{\mathrm{cKO}} ; \mathrm{Nle}^{\mathrm{cKO}}$ mice, attenuation likely results from the activation of the RP/MDM2/p53 ribosome biogenesis surveillance pathway. Upon $A p c$ inactivation, p53 stabilization is observed only locally and transiently in a small population of cells and the intestinal phenotype of Apc loss-of-function is not modified in absence of p53 (this study and [30]). In contrast, high levels of p53 are detected in $\mathrm{Apc}^{\mathrm{cKO}}$; $\mathrm{Nle}^{\mathrm{cKO}}$ crypt and villus cells showing dysfunctional ribosome biogenesis, recognizable by their nucleolar accumulation of precursor rRNAs of the large ribosomal subunit. Contrary to Apc-deficient progenitors, $\mathrm{Apc}^{\mathrm{cKO}}$; $\mathrm{Nle}^{\mathrm{cKO}}$ progenitors are able to exit cell cycle and differentiate. Upregulation by p53 of $p 21$ could be contributing to the restoration of cell cycle arrest and attenuation of the expansion of the proliferative compartment. Another explanation for this attenuation is that $\mathrm{Apc}^{\mathrm{cKO}} ; \mathrm{Nle}^{\mathrm{cKO}}$ progenitors are unable to upregulate protein synthesis at a level sufficient for tumorigenesis. We show here that increased protein translation is an immediate hallmark of $A p c$ loss-of-function that is no longer observed in $\mathrm{Apc}^{\mathrm{cKO}}$; $\mathrm{Nle}^{\mathrm{cKO}}$ progenitors. Enhanced translation likely increases the production of important rate-limiting cell cycle regulators and could influence the capacity of cells to divide or not. Similar to Nle loss-of-function, genetic or pharmacologic inhibition of mTORC1-dependent translational stimulation limits the expansion of the proliferative compartment during tumor initiation [35]. The reduction of the translational potential of $\mathrm{Apc}^{\mathrm{cKO}}$; $\mathrm{Nle}^{\mathrm{cKO}}$ progenitors may therefore contribute to their eventual cell cycle exit and differentiation.

Apc deficiency dramatically modifies the cellular responses of intestinal cells to defective ribosome biogenesis. Indeed, while $\mathrm{Apc}^{\mathrm{cKO}}$; $\mathrm{Nl}^{\mathrm{cKO}}$ stem cells and progenitors express high levels of nuclear p53 and display a clear p53 transcriptional signature, they do not elicit the strong proliferation arrest and apoptotic responses normally observed in crypt cells [22]. Crosstalk between the Wnt/ $\beta$-catenin pathway and p53 have been previously reported and involve the direct or indirect modulation of p53 stability by GSK3 $[40,41]$. However, the regulation of p53 activity by GSK3 leads to p53 degradation, suggesting that this is not the mechanism through which $A p c$ loss-of-function attenuates p53 activation in $\mathrm{Apc}^{\mathrm{cKO}}$; $\mathrm{Nle}^{\mathrm{cKO}}$ crypt cells. Rather, the fate of stem and progenitor cells with an activated RP/MDM2/ p53 ribosome biogenesis surveillance pathway may be modified by the transcriptional response to $\mathrm{Wnt} / \beta$-catenin hyperactivation, such as for example increased expression of Ppan, which has been previously shown to elicit antiapoptotic activities in intestinal stem cells and progenitors [42]. On a different note, it has been shown that the Wnt pathway modulates protein stoichiometry of polysomal ribosomes during mouse neocortex development [43], which, in turns could potentially result in significant modulation of the proteome [44]. If it holds true in the intestine, such qualitative changes in translation may also contribute to the different behaviors of intestinal cells to p53 activation.

It is unclear why intestinal progenitors eventually exit cell cycle in $\mathrm{Apc}^{\mathrm{cKO}} ; \mathrm{Nle}^{\mathrm{cKO}}$ mice. Disequilibrium between the antagonistic actions of Wnt hyperactivation and defective ribosome biogenesis may trigger proliferation arrest. The extended proliferative compartment of the Apc mutant is in many respects heterogeneous, in particular regarding p53 stabilization (this study and [30]) and p21 expression [45], which concern a small population of cells located at the leading edge of the proliferative compartment. It is therefore possible that while leaving the crypt domain, $\mathrm{Apc}^{\mathrm{cKO}} ; \mathrm{Nle}^{\mathrm{cKO}}$ progenitors experience a suprainduction of p53 and p21, which, together with increased concentration of pro-differentiation cues such as BMPs, trigger cell cycle exit. At the same time, $\mathrm{Apc}^{\mathrm{cKO}} ; \mathrm{Nle}^{\mathrm{cKO}}$ progenitors located in the crypt domain are able to proliferate despite defective ribosome biogenesis, giving rise to cells with reduced numbers of ribosomes. Such decrease may also be interpreted as a signal for proliferation arrest, as suggested by the impaired proliferation of primary human cell lines with a defective RP/MDM2/p53 ribosome biogenesis surveillance pathway [46]. 
Our work also unravels major modifications of the Nle loss-of-function phenotype by $A p c$ deficiency. Importantly, our demonstration that $A p c$-deficient stem cells and progenitors are resistant to defective ribosome biogenesis challenges the notion that cancer cells, and in particular c-MYC-driven cancer cells, are more sensitive to ribosome biogenesis inhibition than normal cells [6-8]. Moreover, enhanced survival of stem cells to ribosome biogenesis stress under Wnt hyperactivation conditions may be a major limitation for therapeutic strategies targeting ribosome production, not only for colorectal cancers, but also for other cancers associated with deregulation of the $\mathrm{Wnt} / \beta$-catenin pathway such as cutaneous melanoma, breast carcinoma, hepatocarcinoma or pancreatic ductal adenocarcinoma.

Acknowledgements Imaging analyses was performed at the Imagopole and the histopathology Unit of the Institut Pasteur. We are grateful to the staff of the animal facility of Institut Pasteur for animal care and their help during this work. We thank G. Comai for technical help and advices on RNAscope ISH.This work was supported by the Fondation ARC pour le Recherche sur le cancer (PGA120140200873), the Institut Pasteur, the Centre National de la Recherche Scientifique, the Agence Nationale de la Recherche (ANR-10-LABX-73-01 REVIVE) and the Institut National du Cancer (INCa 2007-1-COL-6IC-1 and PLBIO09-070). A.R. was supported by the Université Pierre et Marie Curie and received fellowship from the French Ministère de l'Enseignement Supérieur et de la recherche, the Fondation ARC pour la Recherche sur le Cancer and the REVIVE Labex. AS received support from the Fondation des Treilles.

\section{Compliance with ethical standards}

Conflict of interest The authors declare that they have no conflict of interest.

Publisher's note Springer Nature remains neutral with regard to jurisdictional claims in published maps and institutional affiliations.

\section{References}

1. Ruggero D, Pandolfi PP. Does the ribosome translate cancer? Nat Rev Cancer. 2003;3:179-92.

2. Fumagalli S, Ivanenkov VV, Teng T, Thomas G. Suprainduction of $\mathrm{p} 53$ by disruption of $40 \mathrm{~S}$ and $60 \mathrm{~S}$ ribosome biogenesis leads to the activation of a novel G2/M checkpoint. Genes Dev. 2012;26: $1028-40$.

3. Bursać S, Brdovčak MC, Pfannkuchen M, Orsolić I, Golomb L, Zhu Y, et al. Mutual protection of ribosomal proteins L5 and L11 from degradation is essential for p53 activation upon ribosomal biogenesis stress. Proc Natl Acad Sci USA. 2012;109:20467-72.

4. Donati G, Peddigari S, Mercer CA, Thomas G. 5S ribosomal RNA is an essential component of a nascent ribosomal precursor complex that regulates the Hdm2-p53 checkpoint. Cell Rep. 2013;4: 87-98.

5. Challagundla KB, Sun X-X, Zhang X, DeVine T, Zhang Q, Sears $\mathrm{RC}$, et al. Ribosomal protein L11 recruits miR-24/miRISC to repress c-Myc expression in response to ribosomal stress. Mol Cell Biol. 2011;31:4007-21.

6. Bywater MJ, Poortinga G, Sanij E, Hein N, Peck A, Cullinane C, et al. Inhibition of RNA Polymerase I as a therapeutic strategy to promote cancer-specific activation of p53. Cancer Cell. 2012;22: 51-65.

7. Peltonen K, Colis L, Liu H, Trivedi R, Moubarek MS, Moore $\mathrm{HM}$, et al. A targeting modality for destruction of RNA polymerase I that possesses anticancer activity. Cancer Cell. 2014;25: $77-90$.

8. Kim DW, Wu N, Kim Y-C, Cheng P-F, Basom R, Kim D, et al. Genetic requirement for Mycl and efficacy of RNA Pol I inhibition in mouse models of small cell lung cancer. Genes Dev. 2016;30:1289-99.

9. Brannon AR, Vakiani E, Sylvester BE, Scott SN, McDermott G, Shah $\mathrm{RH}$, et al. Comparative sequencing analysis reveals high genomic concordance between matched primary and metastatic colorectal cancer lesions. Genome Biol. 2014;15:454.

10. Andreu P, Colnot S, Godard C, Gad S, Chafey P, Niwa-Kawakita $\mathrm{M}$, et al. Crypt-restricted proliferation and commitment to the Paneth cell lineage following Apc loss in the mouse intestine. Development. 2005;132:1443-51.

11. Sansom OJ, Reed KR, Hayes AJ, Ireland H, Brinkmann H, Newton IP, et al. Loss of Apc in vivo immediately perturbs Wnt signaling, differentiation, and migration. Genes Dev. 2004;18:1385-90.

12. Sansom OJ, Meniel VS, Muncan V, Phesse TJ, Wilkins JA, Reed $\mathrm{KR}$, et al. Myc deletion rescues Apc deficiency in the small intestine. Nature. 2007;446:676-9.

13. van Riggelen J, Yetil A, Felsher DW. MYC as a regulator of ribosome biogenesis and protein synthesis. Nat Rev Cancer. 2010;10:301-9.

14. Royet J, Bouwmeester T, Cohen SM. Notchless encodes a novel WD40-repeat-containing protein that modulates Notch signaling activity. Embo J. 1998;17:7351-60.

15. Cormier S, Le Bras S, Souilhol C, Vandormael-Pournin S, Durand $\mathrm{B}$, Babinet $\mathrm{C}$, et al. The murine ortholog of notchless, a direct regulator of the notch pathway in Drosophila melanogaster, is essential for survival of inner cell mass cells. Mol Cell Biol. 2006;26:3541-9.

16. Gazave E, Lapébie P, Richards GS, Brunet F, Ereskovsky AV, Degnan BM, et al. Origin and evolution of the Notch signalling pathway: an overview from eukaryotic genomes. BMC Evol Biol. 2009;9:249.

17. la Cruz de J, Sanz-Martínez E, Remacha M. The essential WDrepeat protein Rsa4p is required for rRNA processing and intranuclear transport of $60 \mathrm{~S}$ ribosomal subunits. Nucleic Acids Res. 2005;33:5728-39.

18. Ulbrich C, Diepholz M, Baßler J, Kressler D, Pertschy B, Galani $\mathrm{K}$, et al. Mechanochemical removal of ribosome biogenesis factors from nascent 60S ribosomal subunits. Cell. 2009;138:911-22.

19. Matsuo Y, Granneman S, Thoms M, Manikas R-G, Tollervey D, Hurt E. Coupled GTPase and remodelling ATPase activities form a checkpoint for ribosome export. Nature. 2014;505:112-6.

20. Barrio-Garcia C, Thoms M, Flemming D, Kater L, Berninghausen $\mathrm{O}$, Baßler J, et al. Architecture of the Rix1-Real checkpoint machinery during pre-60S-ribosome remodeling. Nat Struct Mol Biol. 2015;23:37-44.

21. Le Bouteiller M, Souilhol C, Cormier S, Stedman A, BurlenDefranoux O, Vandormael-Pournin S, et al. Notchless-dependent ribosome synthesis is required for the maintenance of adult hematopoietic stem cells. J Exp Med. 2013;210:2351-69.

22. Stedman A, Beck-Cormier S, Le Bouteiller M, Raveux A, Vandormael-Pournin S, Coqueran S, et al. Ribosome biogenesis dysfunction leads to p53-mediated apoptosis and goblet cell differentiation of mouse intestinal stem/progenitor cells. Cell Death Differ. 2015;22:1865-76.

23. EL Marjou F, Janssen K-P, Chang BH-J, Li M, Hindie V, Chan L, et al. Tissue-specific and inducible Cre-mediated recombination in the gut epithelium. Genesis. 2004;39:186-93. 
24. Guo J, Longshore S, Nair R, Warner BW. Retinoblastoma protein (pRb), but not p107 or p130, is required for maintenance of enterocyte quiescence and differentiation in small intestine. J Biol Chem. 2009;284:134-40.

25. Léguillier T, Vandormael-Pournin S, Artus J, Houlard M, Picard $\mathrm{C}$, Bernex $\mathrm{F}$, et al. Omcg1 is critically required for mitosis in rapidly dividing mouse intestinal progenitors and embryonic stem cells. Biol Open. 2012;1:648-57.

26. Sato T, Vries RG, Snippert HJ, van de Wetering M, Barker N, Stange DE, et al. Single Lgr5 stem cells build crypt-villus structures in vitro without a mesenchymal niche. Nature. 2009;459:262-5.

27. Bray NL, Pimentel H, Melsted P, Pachter L. Near-optimal probabilistic RNA-seq quantification. Nat Biotechnol. 2016;34:525-7.

28. Love MI, Huber W, Anders S. Moderated estimation of fold change and dispersion for RNA-seq data with DESeq2. Genome Biol. 2014;15:550.

29. Bezanson J, Edelman A, Karpinski S, Shah VB. Julia: a fresh approach to numerical computing. SIAM Rev. 2017;59:65-98.

30. Reed KR, Meniel VS, Marsh V, Cole A, Sansom OJ, Clarke AR. A limited role for p53 in modulating the immediate phenotype of Apc loss in the intestine. BMC Cancer. 2008;8:162.

31. Bohin N, Carlson EA, Samuelson LC. Genome toxicity and impaired stem cell function after conditional activation of CreERT2 in the intestine. Stem Cell Rep. 2018;11:1337-46.

32. Pelletier J, Thomas G, Volarevic S. Ribosome biogenesis in cancer: new players and therapeutic avenues. Nat Rev Cancer. 2018;18:51-63.

33. Bastide A, David A. The ribosome, (slow) beating heart of cancer (stem) cell. Oncogenesis. 2018;7:34.

34. Tsoi H, Lam KC, Dong Y, Zhang X, Lee CK, Zhang J, et al. Pre-45s rRNA promotes colon cancer and is associated with poor survival of CRC patients. Oncogene. 2017;36:6109-18.

35. Faller WJ, Jackson TJ, Knight JRP, Ridgway RA, Jamieson T, Karim SA, et al. mTORC1-mediated translational elongation limits intestinal tumour initiation and growth. Nature. 2015;517:497-500.

36. Bruno PM, Liu Y, Park GY, Murai J, Koch CE, Eisen TJ, et al. A subset of platinum-containing chemotherapeutic agents kills cells by inducing ribosome biogenesis stress. Nat Med. 2017;23: 461-71.

37. Cole AM, Myant KB, Reed KR, Ridgway RA, Athineos D, van den Brink GR, et al. Cyclin D2-cyclin-dependent kinase $4 / 6$ is required for efficient proliferation and tumorigenesis following Apc loss. Cancer Res. 2010;70:8149-58.

38. Ashton GH, Morton JP, Myant KB, Phesse TJ, Ridgway RA, Marsh V, et al. Focal adhesion kinase is required for intestinal regeneration and tumorigenesis downstream of Wnt/c-Myc signaling. Dev Cell. 2010;19:259-69.

39. Holik AZ, Young M, Krzystyniak J, Williams GT, Metzger D, Shorning BY, et al. Brg1 loss attenuates aberrant wnt-signalling and prevents wnt-dependent tumourigenesis in the murine small intestine. PLoS Genet. 2014;10:e1004453.

40. Eom T-Y, Jope RS. GSK3 beta N-terminus binding to p53 promotes its acetylation. Mol Cancer. 2009;8:14.

41. Kulikov R, Boehme KA, Blattner C. Glycogen synthase kinase 3dependent phosphorylation of $\mathrm{Mdm} 2$ regulates p53 abundance. Mol Cell Biol. 2005;25:7170-80.

42. Pfister AS, Keil M, Kühl M. The Wnt target protein peter pan defines a novel p53-independent nucleolar stress-response pathway. J Biol Chem. 2015;290:10905-18.

43. Kraushar ML, Viljetic B, Wijeratne HRS, Thompson K, Jiao X, Pike JW, et al. Thalamic WNT3 secretion spatiotemporally regulates the neocortical ribosome signature and mRNA translation to specify neocortical cell subtypes. J Neurosci. 2015;35:10911-26.

44. Genuth NR, Barna M. Heterogeneity and specialized functions of translation machinery: from genes to organisms. Nat Rev Genet. 2018;19:431-52.

45. Cole AM, Ridgway RA, Derkits SE, Parry L, Barker N, Clevers $\mathrm{H}$, et al. p21 loss blocks senescence following Apc loss and provokes tumourigenesis in the renal but not the intestinal epithelium. EMBO Mol Med. 2010;2:472-86.

46. Teng T, Mercer CA, Hexley P, Thomas G, Fumagalli S. Loss of tumor suppressor RPL5/RPL11 does not induce cell cycle arrest but impedes proliferation due to reduced ribosome content and translation capacity. Mol Cell Biol. 2013;33:4660-71. 